\title{
QUATERNARY GLACIATIONS OF NORTHERN EUROPE
}

\author{
Margot Böse ${ }^{1}$, Christopher Lüthgens ${ }^{1}$, Jonathan R. Lee ${ }^{2,3}$, James Rose ${ }^{3,2}$ \\ 1) Freie Universität Berlin, Department of Earth Sciences, Institute of Geographical Sciences, Physical

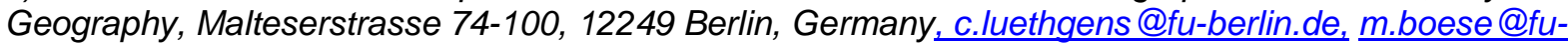 \\ berlin.de \\ 2) British Geological Survey, Keyworth, Nottingham, NG12 5GG, UK, irlee@bgs.ac.uk \\ 3) Department of Geography, Royal Holloway, University of London, Egham, Surrey, TW20 OEX, UK, \\ j.rose@rhul.ac.uk, jrose@dircon.co.uk
}

\begin{abstract}
This paper presents the outcome of a workshop, held in Berlin in February 2009, concerned with current research on the glacial history of northern Europe, including the British Isles. The methodologies presently used to resolve this topic are outlined. Particular attention is given to new analytical methods deriving from high resolution remote imaging of glacial terrain both on land and on the sea-bed, key new stratigraphic sections, higher resolution results from conventional geochronological methods like radiocarbon and more recently developed technologies such as luminescence and cosmogenic radionuclide dating. The relationships between the results derived from these two methods are discussed in further detail along with possible explanations for these differences. An outline of a 'most likely' glacial history of the Scandinavian and British and Irish Ice Sheets is presented along with possible links to global climate change as represented by the marine isotope (MIS) record. Tentative evidence for glaciation is identified in MIS 22, 16, 12, 10, 8, 6, 4 and 2 and correlations of 'phases' within the Last Glaciation are also explored for both the Scandinavian and British and Irish Ice Sheets. The results show that the character and extent of glaciation in different parts of the region are not synchronous and much more geochronological work is required before regional correlations can be established with confidence.
\end{abstract}

Keywords: glaciation, marine isotope stages (MIS), Scandinavian Ice Sheet (SIS), British and Irish Ice Sheet (BIIS), Last Glacial Maximum

\section{Introduction and objectives}

The glaciation of northern Europe has been a subject of interest and debate for over 200 years and today, at a time of greater awareness to the consequences of climate change, the subject retains its relevance to science and society. With the development of new methodologies for dating glacial deposits and important new findings for modelling glacier response to climate change this subject requires re-evaluation and re-interpretation. Likewise it has been possible to identify critical issues that should be the focus for future research. Consequently, in February 2009 an exploratory workshop was held at the Freie Universität Berlin to examine the frequency and timing of glaciations in northern Europe (including Britain) during the Middle and Late Pleistocene. The workshop was funded by the DFG (Deutsche Forschungsgmeinschaft/ German Research Foundation) and involved 24 participants. This issue of Quaternary Science Reviews includes a number of the contributions presented and discussed at the meeting along with certain invited papers that present new findings on the topic of the special issue.

This paper will begin by briefly reviewing the contents of the issue giving particular attention to new and important findings. This will be followed by a section that will evaluate the methodologies currently being applied to understand the glaciations of northern Europe. Some of these methodologies, such as lithostratigraphy and morphostratigraphy, are as old as the subject itself, but their utility has been significantly enhanced by recent improvements in our understanding of glacial depositional processes and new computer-based techniques of representing the stratigraphically significant aspects of landforms both on land and on the sea-bed. The importance of chronological methods for constraining glaciations and determining a glacial history is no less important than it has ever been, but with a realization of the limitations of much biostratigraphic correlation and dating, and a significant improvement in the resolution of existing geochronological methods such as radiocarbon dating and amino-acid racemisation (AAR), many past correlations and timings for glaciation need reevaluation. More important perhaps, the ability to date glaciation directly using optically stimulated luminescence (OSL) or cosmogenic radionuclide dating of glacially derived sediments/ abraded surfaces has fundamentally changed our approach to glacial chronology. Particular attention is given to the application of these methods and problems of interpretation arising from their application. 
The section on methodology will be followed by an attempt to provide an overview of the extent and chronology of glaciation in northern Europe. The results show that this remains a difficult task even after 200 years, but the findings presented in this volume identify critical issues about glacial history that have substance and other issues that require much more work, or even new methodologies. In order to place the responses of northern Europe to global climate change the tentative correlations are placed in the context of global climate change as expressed in terms of marine isotope stages (MIS) and, where possible, sub-Milankovitch changes such as Heinrich Events. These correlations remain tentative, but again the process of making the correlations identifies important issues for future research. Finally, the paper examines the critical processes that have determined the extent of glaciation within the region. In this respect the paper will consider the role of subglacial bed material, hydrology and terrain and the changes of these properties over both long-term $(\sim 500 \mathrm{ka})$ timescales and the timescales of a glacial cycle. These properties are of crucial importance for understanding how glaciers are likely to respond to climate forcing and a necessary pre-requisite for this science if we are to move beyond the process of wiggle-matching.

\section{Brief review of the content of the issue}

The papers in this volume are arranged geographically with the first group being concerned, primarily, with the southeastern and southern part of the Scandinavian Ice Sheet (SIS), beginning with evidence from Sweden then working around the marginal region from Estonia, through Latvia, Lithuania, Poland and Germany. The final paper in this section is concerned with the southwestern part of Norway, although the paper is relevant to the whole of Norway, Sweden and Finland and indeed the British Isles. The second group of papers in the volume concern the effects of the British and Irish Ice Sheets (BIIS) dealing with evidence from the British and Irish land areas and also the adjacent seas. In additional to the regional themes much attention is given to the methods of dating the glacial events, and in this respect relatively new technologies such as optically stimulated luminescence (OSL) and cosmogenic radionuclide determinations play an important role in identifying either new sequences of glacial activity, or re-enforcing long established schemes. Finally, new output from remote sensed imagery of the land surface or sea-bed are used in a number of papers to identify new landforms, resolve previously controversial interpretations of landforms, and establish patterns of glacier behaviour that have, hitherto, not been recognised. The issue of morphostratigraphy is also considered systematically in a separate paper on this development of this topic with regard to the interpretation of the glacial history of northern Germany.

Alexanderson and Murray (2012) present the results of an experiment to determine why, in many cases the OSL determinations produce results that do not accord (usually over-estimate) with the age expected from other, independent methods such as relationship with radiocarbon ages, cosmogenic radionuclide ages and glaciological principles applied to the location and stratigraphic context of the sediments. The experiment is based on a large number of ages taken from a wide range of relevant environments across Sweden, with a number of other determinations from other contexts to provide calibration. The results, expressed most clearly in a bi-ordinate figure Alexanderson and Murray, 2012, Figure 3) show that material from wave washed, aeolian and lacustrine environments provide ages with the lowest deviation from the expected age (derived from the other criteria) and the lowest scatter around the mean value. Conversely subglacial till and glaciofluvial sediment, proglacial glaciofluvial and glaciolacustrine sediments show the largest deviation from the expected value and the largest scatter about the mean. Further analysis shows that deviation from the expected age diminishes with distance in distance and time from the glacial source of the sediment.

Analysis of the results suggests that the error is due to incomplete bleaching, although this is not always the case and the authors admit that in these cases, which usually apply to distal glaciofluvial or wave-washed sediments, the reason for the over-estimated age is not known. They identify that much of the scatter is due to low luminescence sensitivity, but equally, they identify that some materials, such as the Proterozoic Dala Sandstone, or material that have been extensively reworked by Quaternary processes are highly sensitive, with good luminescence characteristics and yield reliable ages. Clearly, reconstructions of the glacial history of Sweden, and of other glaciated area, using OSL need to take into consideration this paper and its recommendations.

The papers by Kalm (2012), Saks et al. (2012) and Bitinas (2012) are concerned with the southeastern margin of the SIS. That of Kalm gives particular attention to the landforms of the regions 
using some most impressive, fine resolution Digital Elevation Models (DEM). These images show streamlined lineaments, some of which are cross-cutting, moraine ridges, and the clear relationship of these glacially formed landforms to the underlying terrain. The records reported here are part of an attempt to build a GIS model of the extent and timing of the last SIS in the region, and the results demonstrate very clearly the position and margins of a number of ice streams that crossed the region during the maximum expansion and subsequent wastage of the SIS.

Saks et al. (2012) present the results of an attempt to date glaciation in the southeastern Baltic region using OSL, the first study of its kind in the area. The analysis is based on the study of freshwater sediments that overlie and are overlain by glacial deposits in the coastal region of Latvia. The interpretation of the sites is complicated by glaciotectonic deformation and the incorporation of organic material within the deposits, derived from pre-existing sedimentary units. Nevertheless the stratigraphy is resolved and the results provide ages that indicate that a freshwater lake filled this part of the Baltic basin during MIS 3, until c. $25 \mathrm{ka}$, and that the overlying till is of Late Weichselian age, and not Saalian as had previously been suggested. Revised ages are also proposed for the underlying glaciogenic and interglacial sediments suggesting that they are of Middle Weichselian and Eemian age respectively, rather than Saalian and Holsteinian.

As part of this revision of the glacial history of the southeastern Baltic region, Bitinas (2012) presents a new model for the deglaciation of Lithuania based on detailed mapping of the glaciogenic landforms and sediments and the use of recently published cosmogenic radionuclide ages (Rinterknecht et al., 2006). Of key importance in this interpretation is the identification of ice disintegration topography in the form of kame terraces, and especially kame terraces on the ice-distal side of moraine ridges. These indicate that the ice had wasted by thinning rather than marginal retreat and that wastage across Lithuania and adjacent countries was associated with a number of different and distinct ice streams. Bitinas is unable to find any evidence of ice-marginal fluctuations or re-advances although he demonstrates that there is evidence of regional asynchronicity along the ice margin associated with the development, expansion and wastage of different ice streams. All the deposits are associated with the Late Weichselian Glaciation.

Both Marks (2012) and Rinterknecht et al. (2012) are concerned with the timing of glacial events associated with the SIS. Marks (2012) brings together all the radiocarbon, OSL and cosmogenic radionuclide $\left({ }^{26} \mathrm{CL}\right.$ and $\left.{ }^{10} \mathrm{Be}\right)$ ages from northern Poland, and interprets them in relation to the glaciogenic landforms across the region. The results suggest that the Late Vistulian (Late Weichselian) ice sheet reached maximum extent between 24 and 19 ka but that this event was diachronous, younging towards the east. Dates that can be related to the landforms associated with the Poznan and Pomeranian Phases of the Late Vistulian, which developed during the retreat of this glaciation, suggest that they formed at 20-19 ka and 17-16 ka respectively. Unlike the interpretations of the evidence from further east (Saks, 2012; Bitinas, 2012) Marks is of the opinion that the different phases were preceded by ice-margin retreat and therefore represent readvances. In addition to the evidence for Late Weichselian glacial activity, Marks reports evidence for a MIS 3 glaciation that reached the region of the southern Baltic Sea and northeastern Poland.

The work by Rinterknecht et al. (2012) reports the results of a project to date the Hoher Fäming region southwest of Berlin and the Gerswalder moraine (a recessional feature within the Pomeranian stage complex) to the northeast of Berlin. All of these areas of higher landare composed primarily of glaciogenic materials and are interpreted as the results of glacial advances. The dating method applied is cosmogenic radionuclide dating of surface boulders using ${ }^{10} \mathrm{Be}$, and follows some earlier work on the Pomeranian moraine (sensu stricto) using the same method (Heine et al., 2009). The results from the Hoher Fäming yield a wide range of ages, extending back to the Saale or Early Weichselian Glaciation and it is suggested that these ages a function of the erosional history of the locality following deposition, resulting in a complex exposure history for the sampled boulders, as a result of valley-side erosion and periglacial disturbance. In contrast, the ages from the Pomeranian stage deposits show a tightly clustered distribution of ages suggesting that the Pomeranian moraine (s.s.) formed between 17.2 and $16.4 \mathrm{ka}$ (which is younger than previously assumed) and the Gerswalder moraine was formed at the margin of the SIS between 16.0 and $15.2 \mathrm{ka}$. These results lead the authors to consider the reasons for the younger ages, relative to previous expectations, and suggest that there may have been a complex readvance or ice-stream history, but recommend that further work is required before an explanation can be proposed with any confidence. 
Johnsen et al. (2012) report the results of OSL dating of fine-grained glaciolacustrine sediments from between tills from a locality some $120 \mathrm{~km}$ southeast of Trondheim in central Norway. The analyses reveal good luminescence properties and narrow range of ages around $22 \mathrm{ka}$, very similar to radiocarbon dates from one of the same localities in the order of $21 \mathrm{ka}$ (Olsen et al., 2001), indicating that the locality was ice free around this time. These ages correlate with the Trofors Interstadial (25 $22 \mathrm{ka} \mathrm{BP}$ ) of the Late Weichselian, an interstadial that separates the classical LGM into two advances. The significance of these determinations extends far beyond the study sites. Firstly, the results support the evidence from across all of Scandinavia (Johnsen et al., 2012, Figure 1) for non-glacial conditions with vegetation cover and a mammoth fauna from the same period of time; and secondly the localities studied are in the source regions of glaciers that flowed southeastwards to the southeastern and southern Baltic margins and westwards to the North. Clearly if these sites, in this ice source region, were ice-free, then it is likely that the down-glacier sites of the southeastern Baltic region, northern Poland and Germany, and the eastern part of the North Sea region where also icefree at the same time.

The paper by Clark et al. (2012) presents the results of a major study of the BIIS that has taken place over the past decade. This research programme has involved the collection of hitherto unimaginable quantities of data ( $>26,000$ landforms) regarding these ice sheets from high resolution DEM images of terrestrial and sea-bed glacial landscapes. Along with this basic information, the project has brought together the results of previously published and unpublished research from Britain and Ireland and from the adjacent seas, along with 881 dates (radiocarbon, AAR, luminescence, U-series, cosmogenic radionuclide) that can be related to the behaviour of the last ice sheet (Clark et al., 2004; Evans et al., 2005). In this paper, the outcome from the analyses of these results is presented as a comprehensive, but thoughtful and cautious interpretation of the history of the BIIS, between the onset of the LGM until, but not including, the Bølling/ Allerød Interstadial (27 to $15 \mathrm{ka} \mathrm{BP}$ ). The results are constrained within a GIS and presented as a model for the extent, activity and timing of the of the BIIS over this period, expressed in the form of a series of maps showing the glacial extent and likely iceflow patterns for a number of time slices.

The first observation to emerge is that, while at its maximum extension, the BIIS behaves as a single integrated unit with an ice-shed across Ireland and Britain aligned parallel to the shelf edge to the west, and a convergence zone with the SIS in the central and northern parts of the North Sea to the east. Secondly, it is proposed on the basis of available dates and ice-flow characteristics that the BIIS reached is maximum extent at different times in different sectors. The maximum extension toward the shelf edge occurred at around $27 \mathrm{ka}$ followed by stability in this region (possibly stimulated by the ice reaching a calving line in the deep water off the continental shelf), whereas the maximum expansion to the south down the Irish Sea and the North Sea coast of eastern England occurred between around 23 and $17 \mathrm{ka}$. Wastage of the BIIS resulted in the ice-sheet retreating to a number of upland source areas with a remaining marine based portion over Orkney-Shetland islands. It is considered that the BIIS had separated into separate British and Irish ice sheets by $16 \mathrm{ka}$ and that ice had disappeared from Britain and Ireland by $15 \mathrm{ka}$ (although it is acknowledged that a case can be made for ice surviving in the western Scottish highlands through the B/I Interstadial (Bradwell et al., 2008a)). Using the palaeoglacialogical reconstructions it is suggested that maximal retreat rates of c. $150 \mathrm{ma}^{-1}$ could have been associated with some of the ice streams and the Late Devensian (Weichselian) BIIS, at its maximum volume contributed $2.5 \mathrm{~m}$ of water depth to global sea-level.

The paper by Ó Cofaigh et al. (2012a) demonstrates the way new technology has contributed to identifying and interpreting glacial landforms; in this case sea-bed landforms. The evidence is taken from the sea-bed off the coast of northwest Ireland, as far west as the shelf-edge. The technology used in the study is Multibeam swath bathymetry collected through the Irish National Seabed Survey, and the results show with quite remarkable clarity, sets of streamlined lineaments and complex associations of nested arcuate moraine ridges, as well as traces of iceberg ploughing. The reason for the development and preservation of these features is, respectively, their formation in readily deformable sea-bed sediments and their preservation on the sea-bed below the wave-base and away from subaerial weathering and erosion. Interpretation of this evidence suggests that massive moraine ridges developed at the shelf-edge at the margin of a linear ice sheet, and that subsequently smaller moraine ridges and associated streamlined bedforms (drumlins) developed in response to a lobate ice margin sourced from adjacent ice streams draining the Irish and Scottish ice sheets and being subject to occasional minor readvances. Age estimates for the formation of these moraines, by comparison 
with the IRD record from adjacent deep sea cores suggests that the outer ridges formed between 29 and $27 \mathrm{ka} \mathrm{BP}$, while the lobate ridges formed after $24 \mathrm{ka} \mathrm{BP.}$

In a different paper, Ó Cofaigh et al. (2012b) examines the glacial landforms and sediments of southern Ireland that pose a problem, somewhat similar to that identified in the papers around the southeastern and southern margin of the SIS: what is the age of the moraine complexes that are conspicuous on the landscape? In Ireland, the traditional interpretation has been that the South Ireland End Moraine represents the limit of the Last Glaciation and landforms and deposits outwith this feature are the products of an earlier glaciation, an interpretation that has been reinforced by the presence of fossil shoreline deposits that were attributed to a previous interglacial high sea-level. As a result of a detailed OSL dating programme reported in this paper, and existing radiocarbon dates (Ó Cofaigh and Evans, 2007), it is demonstrated that the palaeoshoreline formed during MIS 4-3 with a level determined by glacio-isostatic deformation, and that the glacial deposits previously considered to have formed prior to the Last Glaciation were formed by a rapid and short lived advance (surge) around $24 \mathrm{ka}$ BP. Ireland was therefore almost completely submerged beneath the ice sheet of the Last (MIS 2) Glaciation.

The issue of pre-MIS 2 glaciations is examined in the paper by Davies et al. (2012) which provides a detailed examination of the earlier part of the stratigraphic sequence at a long-studied site in northeast England. The site in question (Warren House Gill in County Durham) has been known for pre-LGM till and raised beach deposits and has been interpreted as evidence for Scandinavian-sourced glaciation of eastern England in MIS 6. A detailed study of the stratigraphy, sedimentology, structures, micromorphology and lithology, along with an attempt to date appropriate materials using AAR and OSL finds no compelling evidence to substantiate a Scandinavian ice source, and suggests that the best age estimate for the glaciation is sometime between MIS 12 and 8 .

The issue of glaciation prior to the Late Weichselian is considered by Lee et al. (2012) with respect to the British Isles, the Netherlands and Norway and the adjacent marine areas. The paper provides a critical review of all the evidence from these regions in terms of IRD signals from marine sites, erratic indicators of glaciation in fluvial and marine sediments, and glaciogenic materials both on land and on the sea-bed. Although the dating of the glacial events is far from precise and in most cases far from secure, the evidence from the three regions and the offshore areas reveals a consistent pattern. The earliest evidence of glaciation consists of IRD from continental margin sediments, deposited around 2.7 to $2.6 \mathrm{Ma}$. From this period until around $1.1 \mathrm{Ma}$ there is evidence for local glaciation in the mountain regions, but capable of feeding sediments into the outflowing river systems and contributing to sedimentation in the adjacent lowlands. Evidence for lowland glaciation is recorded after $1.1 \mathrm{Ma}$, although the timing of the first substantial glacial deposits in Britain, for instance, remains controversial (Rose, 2009) with conflicting views as to whether the event occurred in MIS 16 or 12 . Conventionally, MIS 12 (Elsterian of northern Europe, Anglian of Britain) was the first time that widespread lowland glaciation extended across Britain and northern Europe, but even this has to be re-examined following evidence that the first lowland glaciation of the Netherlands occurred in MIS 10 (Vandenberghe, 2000). There is substantial evidence for glacial expansions across lowland regions between MIS 12 and 2, but the attribution to particular marine isotope stages, during which there were large global ice volumes, remains confused and controversial, although the maximum expansion of ice across the Netherlands is confidently attributed to MIS 6 . The reason for this debated is the absence of suitable, robust and reliable dating methods.

Thierens et al. (2012) present the results of an investigation to determine the occurrence and age of glaciation in the British Isles using the IRD fraction preserved in a core taken from the Challenger coral carbonate mound off the Irish northeast Atlantic continental margin. SEM of sand grains is used to confirm the glacial process and radiogenic isotope source fingerprinting, along with the lithology of the coarser IRD component, is used to provenance the material. The results show that the BIIS has been contributing IRD at irregular intervals since c. 2.6 Ma with events related specifically to the MIS 72-74, 62-54, 54-36 and to all MI glacial stages since MIS 12 . These results are especially important as they mean that at these times, ice reached the coastal margins with sufficient dynamic to shed icebergs into the coterminous ocean and so produce the IRD.

A number of general issues emerge from these studies, and many are considered below. However in Lüthgens and Böse (2012) the authors examine the reliability and significance of OSL dating of glaciofluvial outwash and cosmogenic radionuclide dating of glacially exposed surfaces, in particular 
on moraine ridges. The issues are considered in the context of the glacial history of northern Germany, where there is a long research history, and especially the area around Berlin. It is stressed that OSL and surface exposure dating of the same landform cannot produce the same age as the two methods date different processes in the development of a landform. OSL ages on outwash which dates the active process of sedimentation will give a maximal age because of the likelihood of incomplete bleaching, whereas cosmogenic radionuclide ages on boulders, which dates the stabilization of the landscape and the retention of the boulder in an exposed position will give a minimal age because boulders may move due to periglacial soil processes, disturbance due to melting ice, and rotation due to gravitational mass movement.

\section{Methodologies \\ 3.1 Morphostratigraphy}

\subsubsection{Traditional Morphostratigraphy}

The development of morphostratigraphy and the next step towards modern geochronology are the subject of the paper by Lüthgens and Böse in this volume. Even today most authors refer to the morphostratigraphy of their research area, as this stratigraphic property provides a general areal framework for the study and in most cases justifies the choice of sampling sites for geochronological studies.

The boulders in the north German landscape were of great interest to the early natural sciences. Several theories on the origin of the boulders were discussed, a prominent one being the drift theory as a consequence of a big flood (cf. Buckland, 1823). The idea of glaciations covering major parts of northern Europe, including northern Germany, can be seen in the context of the glacial theory developed in the western Alps (Bernhardi, 1832). But the idea of a glaciation in northern Germany was 'officially' accepted only after Otto Torrell's momentous visit to the limestone quarry of Rüdersdorf, west of Berlin, in 1875 and his identification of glacial striations on the Muschelkalk. Striations as a relic of glaciation had already been described in Sweden by Sefström in 1838. Geologists of the Preussische Geologische Landesanstalt (Prussian Geological Survey) thereafter applied this theory in maps and publications relating to the northern German landscape and to the landscape as far east as the Baltic region. The time was ripe for the acceptance of a Nordic glaciation reaching far to the south and the climatic changes it implied.

This idea was also transferred from the Alps (Agassiz 1840) to Scotland, Wales, England and Ireland during a stay by Agassiz in these areas, although initially the glacial concept was not widely accepted by mainstream British researchers. Finally, Lyell and like-thinking colleagues adopted the idea of a glaciation (Ehlers 2011).

From the origin and transport of the boulders, in the sense of erratics, it was a short step to the interpretation of the genesis of landforms. After the introduction of polyglacialism in Northern Germany by Penck (1879), morphostratigraphy was the basis of a first attempt to classify "older" and "younger" glacial landscapes. It was a challenge to develop models for the systematic organisation of a landscape, and the "Glaziale Serie" proposed by Penck (1882) was one such model, and is still applied in central Europe today. It combines the concept of a regular sequence of morphostratigraphic units such as the erosional basin, dead ice hollows, meltwater channels, eskers, kames, end moraines and outwash plains, which were considered to characterise an ideal type of glacial landscape. Penck was the first to combine the landforms with their sedimentological characteristics, thus involving also the formation processes.

The need to determine the relative time of formation of distinct landforms remained a problem. For instance, the first integrative maps by Keilhack (1909), of the southwestern fringe of the Scandinavian ice sheet show the prominent end moraines of the Warthe (Warta-) Stadial of the penultimate glaciation (Saalian), as belonging to the Last Glaciation because of their well-developed and distinct forms. Very few minor ice marginal positions had so far been detected west and south of this limit. Contemporary scientific discussion was dedicated, at least indirectly, to finding clear topographic criteria by which to distinguish glacial landscapes of different ages.

Gripp (1924) finally made a detailed study of northwestern Germany by comparing topographic maps on the scale 1:25,000 in the area under question. He was the first to take not only the altitudes of end 
moraine complexes, but also the occurrence of lakes and dead ice hollows as criteria to distinguish young and old morainic areas. The identification of morphostratigraphic diversity of a landscape was a new approach to the study of end moraines. Gripp (1924) identified the outer limit of the Last Glaciation and in general, this remains valid today. The southernmost extension of the Elsterian glaciation and the western reaches of the Saalian glaciation are documented by means of lithostratigraphy - by the occurrence of Nordic erratics and flint - because in these cases the morphology has been reshaped by long-term erosional processes and the glacial topography is indistinct in many places.

Two maps present the synthesis of morphostratigraphic interpretations. One, by Woldstedt (1935) covers the area from present-day southern Lithuania to the Netherlands. On this figure red lines show the main ice marginal positions (Haupteisrandlagen) as reconstructed from the morphology; hatched areas include the whole complex of push moraines where the author was not yet sure, or convinced, that they belong to the penultimate glaciation, as proposed by Gripp (1924) for the western parts. The other map, by Liedtke (1975) covering a similar area also shows distinct ice marginal positions as brown lines, whereas the southern- and westernmost extensions of the Middle Pleistocene Nordic glaciations are again marked by dotted lines and predominantly based on the occurrence of flint. Besides the thick brown lines used to indicate the main marginal positions, thin brown lines are used to mark minor or recessional positions. The marginal positions are frequently linked with outwash plains which extend down to the ice marginal valleys to the south and southwest.

For decades, traditional morphostratigraphy has provided a useful tool for structuring glacial landscapes. Presumed palaeo-ice sheet extents are depicted as static lines over long distances, not always verified by well-defined end moraines. Thus, in many places the lines represent a model and not the morphological reality. The lines also imply a stable, synchronous ice margin over long distances. Regional and local responses of the glacier margin due to the ice dynamics, different nourishment by varying precipitation on the western, southern or eastern fringes of the inland ice, underlying topography and rock properties have no place in this static concept. For decades, morphostratigraphy has been the basis for a relative chronology of glaciations, glacier advances and deglaciation in the glacial landscape.

It is interesting to consider the papers in this volume in term of the above. $\mathrm{O}^{\prime}$ Cofaigh et al, (2012b) examine the significance of the South Ireland End Moraine, which had been identified on the basis of traditional morphostratigraphy, using radiocarbon and OSL geochronology, only to find that this feature can no longer be used to identify the limit of the Last Glaciation. Likewise, Clark et al. (2012) demonstrate the asynchronicity of the morphostratigraphic units (for instance, moraines in east Yorkshire, northwest Midlands, and the southern Irish Sea region), as all the dating evidence demonstrates that these similar 'fresh' landforms formed at different times. This same issue is developed and clearly explained by Bitinas (2012) with evidence from Lithuania, by Marks (2012) with evidence from northern Poland, and by Lüthgens and Böse (2012) with evidence from northern Germany.

\subsubsection{Developments in Morphostratigraphy}

Traditionally, as described above, morphostratigraphy had developed as a method for the identification of ice margins, using moraine ridges and outwash features, and for the determination of ice flow directions using directional indicators such as drumlins. With the detailed work of Sissons in Scotland (1967) glacial morphostratigraphy moved to a new phase with the identification of slopes and surfaces according to their process of formation. Using analogue studies from currently glacierised regions, features such as ice-contact slopes, terrace surfaces and river channel sides were identified and integrated to identify such features as kame terraces, meltwater channels, moraine ridges, eskers, kettle holes, etc. The consequence of this detailed work in areas like Britain was considerable, revising many concepts and adding a new level of reliability to the interpretation of the glacial, periglacial and shoreline history of regions (Rose and Smith, 2008). However, within the British Isles, where landscape degradation under present climate conditions is high, this method was mainly applicable within the area of the Younger Dryas glaciation or the deglacial parts of the LGM and it was not possible to apply these techniques effectively in areas formed during the maximum extension of the Late Devensian (Weichselian) LGM where the traditional studies of the Nineteenth Century were significantly not advanced (Mitchell et al., 2010). It is interesting to note that in the more continental 
climate of eastern mainland Europe many of these older landforms are much less degraded, as demonstrated by the work of Bitinas (2012).

A significant advance on this methodology was developed by Boulton et al. (1985) and subsequently developed in Boulton et al. (2001) by which he traced the ice flow path using glacial lineaments (drumlins, streamlined hills) and wherever possible tied these ice-flow directions to marginal features such as moraine ridges, linking both of these to relevant dates where these exist. Although this is very simple and had been done in detail on numerous occasions, the regional patterns clearly identified the main ice-streams of an ice-sheet (Figure 1). This method expanded to new dimensions with the availability of satellite imagery and the methodology was applied with equal success to the Laurentide Ice Sheet (Boulton and Clark, 1990). In this fashion morphostratigraphy could provide a robust but not particularly refined model for glacial behaviour of a particular ice sheet.

With the development of high resolution DEMs of glaciated terrain, such as the availability of NEXTMap ${ }^{\mathrm{TM}}$ for the British Isles, a new level of landscape interpretation that is applicable to features produced across the whole of the last Glaciation, became possible, as seen in the paper by Kalm (2012). An evaluation of the data collected from remote imaged DEMs has been reported in Smith et al. (2006), and some limitations are identified, but the quality of the evidence, its universal applicability across a terrain, and the ability to see patterns that may not be visible on the ground, takes morphostratigraphy far beyond what is possible with field mapping, except for the need to ground-truth features and of course examine the rocks that comprise the landform. It is data of this type that underpins the work of Clark et al. (2012), and this paper clearly sets a benchmark for the morphostratigraphy of the Last Glaciation in Britain. Clark et al. (2012) set out the techniques they use and the processes by which they use the data collected, in order to interpret the glacial history of an area. Some of the detail that can derived using NEXTMap ${ }^{\mathrm{TM}}$ is illustrated very clearly in Livingstone et al. (2011) for northwestern England where there is a very complex history of ice movement. NEXTMap ${ }^{\mathrm{TM}}$ has a nominal resolution of $5 \mathrm{~m}$ and a vertical accuracy of $1 \mathrm{~m}$ (Smith et al., 2006), but even this detail can be improved-on by the use of LiDAR imagery which has a resolution of $2 \mathrm{~m}$ and a vertical accuracy of $0.25 \mathrm{~m}$. In most cases this improvement in the resolution is not needed, especially with respect to the study of large areas of terrain shaped by glaciers during the Last Glaciation maximal expansion, but as shown in Smith et al., (2006), within areas shaped by the Younger Dryas glaciers, where the detailed texture of the glacial landscape remains, then the finer resolution of the LiDAR imagery can be important. An example of a study of this kind is illustrated in Livingstone et al. (2010a, b) (Figure 2, taken from Livingstone, 2010a) which shows the quality of the evidence available, with the potential use of this evidence clearly provided in the text of these two papers.

A similar revolution has taken place with regard to our ability to acquire morphostratigraphic evidence, particularly from the Last Glaciation, from the sea-bed. Evidence of this type is presented and analysed by O' Cofaigh et al, (2012a), providing an entirely new level of information about an area far beyond the reach of conventional mapping methods. The work of Bradwell et al. (2008) also shows the remarkable results obtained in regions where the texture of the glacial landscape has not been degraded by sub-aerial processes (Figure 3 ). In this case the results clearly resolve the issue of whether the British and Scandinavian ice sheets were contiguous and the areas of the North Sea that they covered by ice, along with their direction of movement and glacier behaviour. Both of these studies use acoustic bathymetry.

It is evident that with these new, very high resolution and high accuracy techniques that morphostratigraphy has moved into a new level and provides an authoritative body of information that must underpin future studies of glacial sediments, the processes of formation of glacial landforms and studies of the palaeoglacialogical history of a region.

\subsubsection{Morphostratigraphy - a perspective}

Despite the confidence expressed at the end of the above section, and the ability of morphostratigraphy to provide an ordering of ice-marginal landforms, the quality of the interpretation does depend upon the resolution of the terrain with respect to both the landforms studied and the morphostratigraphic method applied and, as shown in (Lüthgens and Böse, 2012), there are a number of draw-backs that limit its applicability. Firstly, it is assumed that the absolute and relative age of the landforms are well constrained, and in some/ most areas this has proved problematic (Lüthgens et al., 
2010). Secondly, it assumes that rates of landscape preservation and degradation are timedependent. Whilst this may be true to a degree, it overlooks the propensity of different materials forming the morphology to degrade at different rates, and the role played by buried ice and 'landscape inversion' upon mass wastage in shaping the ice-marginal morphology (Everest and Bradwell, 2003). The study by Ó Cofaigh et al. (2012b) clearly demonstrates this problem. In this case the attribution of the 'fresh' 'younger drift' to the Last Glaciation, and the 'degraded' 'older drift' to earlier glaciations is invalid, when tested using high quality radiocarbon and OSL dates.

Much recent research in northern Europe, as demonstrated by a number of papers in this volume, has focussed upon examining the Last European Ice Sheet and its component ice sheets (BIIS, SIS), and upon defining the maximum extent of these ice sheets (the regional LGM) relative to the global LGM, as well as their spatial and temporal style of deglaciation. As reflected in a number of papers in this issue (Bitinas, 2012; Marks, 2012; Rinterknecht et al., 2012; Lüthgens and Böse, 2101; Clark et al., 2012; O'Cofaigh et al., 2012b) the systematic attempt to tie the morphostratigraphy to the geochronology marks a significant shift in approach, whereby ice-marginal positions are based upon absolute chronology (usually ${ }^{14} \mathrm{C} / \mathrm{AMS}$, OSL or cosmogenic radionuclide exposure dating) rather than morphological association. From this approach, time-slice isochrons may be used to construct a detailed picture of how ice-marginal positions evolve through time (a method attempted by Boulton et al. $(1985,2001)$, but without the strict dating control). This approach assumes that the whole icemargin does not operate synchronously, but asynchronously, and is driven by independent glaciological controls that operate in a time-transgressive manner (Marks, 2002; Houmark Nielsen, 2004).

This morphostratigraphic approach lends itself in particular to examining both the temporal evolution of ice streams, which are known to exert a major control on the stability of ice sheets, and the more stable margins of ice sheets. When linked to landform data (Stokes and Clark, 2001; Clark et al., 2004; Evans et al., 2005; Bradwell et al., 2007; Bradwell et al., 2008a; Kalm, 2012; Ó Cofaigh et al., 2012b), and sedimentological, lithological and other directional data (Lunkka et al., 2001; Kjær et al., 2003; Gałązka, 2004; Houmark Nielsen, 2004; Rinterknecht et al., 2006), it provides a detailed insight into the dynamics of ice margins, especially the and style and speed of deglaciation. To date, this has been largely applied to a regional scale, although the paper by Clark et al. (2011) provides a review of the whole BIIS.

\subsection{Lithostratigraphy}

\subsubsection{Lithostratigraphy - important concepts}

Lithostratigraphy is defined as the classification of geological units (rock, superficial or soil) based upon their lithological properties and relative stratigraphic superposition (Salvador, 1994; Rawson et al., 2002). Lithostratigraphy is formally constructed around a series of designated stratotype localities where type-properties and relationships can be observed and this approach has previously been widely applied to the Quaternary (e.g. Bowen, 1999). However, application of a 'pure' lithostratigraphic approach to Quaternary stratigraphy is fraught with difficulties especially when correlating glacigenic deposits. It is clear that lithological (dis)similarity alone cannot be used to assume chronostratigraphic equivalence due principally to the complexity of glacial and surface processes, level of preservation and the high temporal resolution of the Quaternary record relative to other parts of the geological record (Lee et al., 2008; Rose, 2009; Hughes, 2010).

Research within modern glacial environments has demonstrated the extreme temporal and spatial complexity of sediment facies, facies architecture and lithological composition (Benn and Evans, 2010). Consequently, glacial sequences are rarely 'layer-cake' even in lowland terrains but frequently defined by multiple bounding surfaces or discontinuities (i.e. erosional surfaces, glaciotectonic structures, palaeosols). This reflects the highly dynamic nature of the glacial environment, the range of erosional, depositional and glaciotectonic processes that occur during successive phases of ice movement, and processes of mass-wasting and landscape inversion that occur during and after deglaciation (Aber et al., 1989; Ballantyne, 2002; Evans and Twigg, 2002; Everest and Bradwell, 2003; Van der Wateren, 2005; Benn and Evans, 2010). Perhaps the most significant development in our understanding of glacial processes over the past 30 years has been the realisation of the role played by 'subglacial deformable beds' in controlling ice dynamics and spatial variations in till composition (Boulton and Jones, 1979; Benn and Evans, 1996; Boulton, 1996; Murray, 1997; Kjær et 
al., 2003; Larson and Mooers, 2005; Evans et al., 2006). Thus, whilst tills are often considered as laterally persistent datum horizons, spatial complexities in their composition and genesis often leads to their composition being heterogeneous at local or regional scales (Perrin et al., 1979; Kjær et al., 2003; Boston et al., 2010; Scheib et al., 2011). Consequently, the use of specific 'type' characteristics or stratotype localities for glacigenic deposits can often prove misleading as they are not truly representative of the genetic / lithological / geometric variability (Rose and Schlüchter, 1989).

Many stratigraphers now adopt a more holistic approach to glacial stratigraphy and stratigraphic correlation utilising an understanding of glacial processes in combination with geomorphology (morpho-stratigraphy), structural geology (tectono- or kineto-stratigraphy), sub-surface geometry and bounding surfaces (allo-stratigraphy), together with the traditional lithostratigraphic approach, and where appropriate or possible, geochronology. Hybridised versions of these stratigraphic approaches are now widely applied to many onshore and offshore Quaternary successions in northern Europe (Larsen and Andersen, 2005; McMillan, 2005; Rijsdijk et al., 2005; Sejrup et al., 2005; Weerts et al., 2005; Rose, 2009; Stoker et al., 2009; Hughes, 2010; Lüthgens et al., 2010).

\subsubsection{Lithostratigraphy - applications}

Lithological differences and characteristics play an important role in traditional Quaternary stratigraphical research. Two main methods of lithostratigraphy have been applied to glacigenic deposits at the southwestern and southern margins of the SIS: indicator boulder counting and gravel analysis. Initially, the source areas of erratic boulders played an important role, but this was soon superseded by attempts to reconstruct ice flow directions (Martin 1898). Crystalline rocks with definite source areas attracted increasing interest (Petersen 1899/1900, Martin 1906, Milthers 1909, Korn 1927). The indicator boulder method requires a considerable number of boulders per sample because of the relatively small number of indicator boulders that are available to be identified, and the numbers have to be sufficient for statistical evaluations such as those proposed by Hesemann (1932) or Lüttig (1958; (TGZ -Theoretisches Geschiebezentrum; Smed, 1989). A summary of various methods can be found in Schuddebeurs (1980-1981). The indicator boulder methods can preferably be applied to cliff sections and large artificial sections, as those are the places where enough material is available, but "Lesesteinhaufen" (heaps of cobbles and boulders collected from fields) have also been used as sources for local studies.

In 1897, Ussing and Madsen (1897) developed the stone counting method, based on studies by Rørdam (1893), for application by the Danish Geological Survey. The size of the stones used was 2$10 \mathrm{~mm}$, and so the method was also applicable to samples, such as borehole cores that contain gravels. Both methods - indicator boulder counting with the identification of restricted source areas and gravel analysis with a quantification of different rock types - have often been applied in the same areas.

A method related to Danish stone counting was used in the former East Germany (GDR) by Cepek (1962) and co-workers in several publications, and was elaborated as an official standard called TGL (Technische Normen, Gütevorschriften und Lieferbedingungen) 25 232. A well-developed application of this gravel counting method has resulted in the GDR's "Lithofazieskarte Quartär" (map of the lithofacies, scale 1: 50,000), that was constructed mainly on the basis of borehole samples. As TGL was applied very rigidly and to the whole territory without any regional variations, it led to misinterpretations because a dynamic ice sheet, by definition, brings different material into different parts of Germany simultaneously. Thus, correlation of similar lithological assemblages across distances was inappropriate rather than valid and should have been avoided. For the Saalian glaciation in particular, the lithostratigraphy of eastern Germany had to be revised in the 1990s (Lippstreu 1995).

Nunberg (1971) gives an example of the application of the gravel counting method in Poland, and recently Górska-Zabielska (2008) has presented indicator boulder studies from Germany and Poland. In the Baltic Republics, Dreimanis (1939), Gaigalas and Gudelis (1965), Gaigalas (1976) and Viiding et al. (1971) have used erratic boulder and gravel analyses for stratigraphical purposes. Numerous studies have also been published in Denmark, northwestern Germany and the Netherlands (HoumarkNielsen 1983, Schuddebeurs and Zandstra 1983).

In addition, lithostratigraphy has been used to distinguish mainly tills of different ice advances and glaciations, thus implying that ice flow directions changed from one glacial period to the next and even 
within a glaciation, such as the shift from more northerly to easterly directions, bringing material (including dolomite) from the Baltic source area into the so-called East Baltic tills (Meyer 1983, 2005; Böse 1990).

Heavy-mineral analyses have also been used to characterise till layers, but this method did not have much impact in lithostratigraphy as it has not lead to meaningful interpretations with respect to correlation of tills and the reconstruction of ice flow directions (Hentschke and Stephan 1989, see also: Peuraniemi 1990).

In Great Britain, glacial deposits have been studied on a more regional scale, based on heavy minerals and the carbonate content derived from underlying bedrock (Catt and Penny, 1966; Perrin et al., 1979) or from trace element geochemistry (Boston et al., 2010; Scheib et al., 2011). Several studies have also recently employed the use of derived micro-fossils together with erratic clast lithologies to reconstruct local ice flow paths (Lee et al., 2002; Riding et al., 2003; Davies et al., 2011, 2012). Till fabric analyses, though also used in the area of the SIS (Ehlers and Stephan 1983), are more frequently used to study the smaller and the more morphology-controlled British glaciation (West and Donner, 1956; Rose, 1974), and studies of the varying granulometric characteristics have also contributed to the interpretation the glaciation of Britain (Perrin et al., 1979).

Lithological analyses of borehole samples, as part of stratigraphical interpretations, have opened up the possibility of obtaining information about the extent of stratigraphical units. The huge brown coal pits in the glaciated areas of eastern Germany and Poland have allowed detailed mapping and sampling of the Quaternary cover deposits (Eissmann 2002, Krzyszkowski 1995). Outcrops also offer the opportunity to define type localities. Apart from the use of biostratigraphy for the interstadials and interglacials, lithostratigraphy is still one of the basic methods for the determination of Quaternary stratigraphy. As the recent compilation of the Quaternary stratigraphy of Germany has clearly documented (Litt et al., 2007), geochronological data are still extremely rare and lithostratigraphy remains one of the basic concepts.

\subsection{Dating methods}

\subsubsection{Preliminary comments}

The issue of dating Quaternary glaciations has engaged Earth Scientists since the origins of the subject (Geikie, 1894). Traditional and typical methods include counting the number of different glacial deposits within a region, differentiating the number of glaciations on the basis of landform freshness (see above for further elaboration of both these issues), and establishing the relationship between glacial deposits/ landforms and other evidence such as bio- and lithostratigraphy that can be used to give an age estimate (Rose, 2009), but inevitably these methods provide results that are open to question because they involve the interpretation of relationships, for which evidence may be controversial and correlation which may be based on tenuous links, or an unsound age estimate for the unit with which the correlation is being made. Unquestionably the key advance came with the ability to date the products of glaciation directly using a geochronometric method, and in this respect OSL dating of glaciogenic materials and cosmogenic radionuclide dating of surfaces exposed by glaciation are, at present, the key methods. The statement is self-evidence in the context of this volume and virtually all the papers involve the application of at least one, and sometime both of these methodologies. Those papers which do not, use the evidence of IRD from stacked sequences of ocean sediments, aided on occasions by FAD/ LAD biostratigraphy and palaeomagnetism, and although there is an element of robustness in the long sequences, this method still involves inferences based on the assumption of continuous sedimentation and the faithfulness of the link to the Milankovitch driven climatic signal. Therefore the crux of future dating of glaciations and a realisation of their spatial variation and dynamics depends upon the quality of the results provided by OSL and cosmogenic radionuclide exposure dating. The latter method has been considered in some detail in Rinterknecht et al. (2012) and the text below will examine the role of OSL with respect, particularly of the dating of terrestrial glaciation.

\subsubsection{OSL dating of glacial sediments}

Luminescence dating techniques are radiometric dating methods and rely on the nature of nonconductive minerals such as quartz and feldspar which store measurable radiation damage caused by naturally occurring ionising radiation within their crystal lattices (Bøtter-Jensen et al., 2003). This 
latent signal is preserved as long as the minerals are sealed from daylight (burial). Once the minerals are exposed to daylight (transport), this signal is reset to zero (bleached). The latent luminescence signal accumulated during the time of burial can be measured in the laboratory with its intensity representing the amount of stored energy within the crystal (equivalent dose De; Bøtter-Jensen et al., 2003; Preusser et al., 2008). Once the rate of stored energy per time (dose rate) is known, the time which passed since the last exposure of the minerals to daylight can be calculated according to the basic age equation

age $(\mathrm{a})=$ equivalent dose $(\mathrm{Gy}) /$ dose rate $(\mathrm{Gy} / \mathrm{a})$.

In the late 1970s and early 1980s thermoluminescence dating techniques (TL, using heat to stimulate the luminescence signal), developed primarily for the dating of heated archaeological materials and artefacts (Aitken et al. 1964), were also used for the dating of sediments (Wintle and Huntley, 1979). However, for sediment dating purposes, these were soon replaced by optically stimulated dating techniques (OSL, using light for the stimulation) developed in the 1980s (OSL - Huntley et al., 1985 and IRSL - Hütt et al., 1988). The major advantage of OSL compared to TL is the fact that the OSL signal is more quickly and thoroughly bleachable by daylight (Godfrey-Smith et al., 1988), allowing age determination of materials that have been transported and then deposited in fluvial or glaciofluvial settings where the mineral grains are only exposed to daylight for short periods of time relative to exposure in other environments such as aeolian. A second boost in the applicability of OSL for the dating of sediments was brought about by the introduction of the single aliquot regenerative (SAR) dating protocol (Murray and Wintle, 2000, 2003; Wintle and Murray, 2006). During the 1990s a number of single aliquot techniques were put forward, but the SAR protocol has by now been established in luminescence dating laboratories worldwide. In contrast to previously used multiple aliquot techniques, all measurement steps necessary to determine the equivalent dose are conducted using the same subsample (aliquot). As a consequence, the equivalent dose of a large number of single aliquots can be determined and ages can be based on a robust statistical analysis of the obtained datasets.

Initially the SAR protocol had been developed for the dating of quartz, but a number of OSL dating protocols based on the SAR protocol has been developed and modified so that they can be used for the dating of feldspar (Wallinga et al., 2000, Huot and Lamothe, 2003). The advantage of feldspar as opposed to quartz is its higher saturation level, which originates in a higher capacity of storage of energy, resulting in a potentially higher age range to be dated. However, the datable age range is dependent on a number of factors such as dose rate (which itself is highly dependent on the lifetime water content of the sediment), targeted luminescence signal and specific luminescence properties of the sampled material. As a rule of thumb, nowadays quartz OSL can successfully be applied to sediments within an age range from only a few decades (Wintle, 2008a) to $-150-250$ ka (Wintle, 2008b), with higher ages possibly obtained from low doserate environments (Wintle, 2008a). When feldspar is used as a dosimeter, the potentially higher age range is highly dependent on the occurrence of anomalous fading (a loss of OSL signal over time) which is as yet poorly understood. Different approaches have been developed to deal with this problem, including methods of fading correction after the OSL measurements (Huntley and Lamothe, 2001), as well as the development of measurement protocols attempting to minimize fading by, for instance, using measurements at elevated temperatures (Thomson et al., 2008). Concerning the methodological details as well as advantages and drawbacks of specific luminescence dating techniques, we refer to a number of recently published review papers and the literature cited therein (Lian and Roberts, 2006; Preusser et al., 2008; Wintle, 2008a, b).

Despite its potential usefulness and applicability for dating glacial and glacially related sediments, luminescence dating has as yet not been very widely applied in glacial sedimentary environments, and this volume is something of a benchmark in this study. The late application of the technique to glaciogenic sediments is probably due to the concern that the sediments may not have been sufficiently exposed to daylight during transport before finally being deposited (Fuchs and Owen, 2008). Insufficient light exposure leads to incomplete bleaching of the OSL signal and an unknown residual signal remains. Incomplete bleaching, if not detected, therefore leads to overestimation of the depositional age (Duller et al., 1995). However, recent advances in luminescence dating techniques, especially the dating of small aliquots or even single grains (Duller, 2006) enable the detection of incomplete bleaching and the identification of the well bleached proportion of a sample for the calculation of a depositional age. For the methodological details of how to cope with incompletely 
bleached sediments we refer to the review paper of Fuchs and Owen (2008) and Houmark-Nielsen (2008), with the latter focussing on southern Scandinavia.

Despite the historical development of luminescence dating of glaciogenic sediments it is important to point out that luminescence dating has significantly promoted our understanding of the timing of the growth and decay of the SIS as well as its response to climate change (Svendsen et al., 2004), and has provided geochronological links to the North Atlantic deep-sea records (Larsen et al., 2006). From a regional perspective, luminescence chronologies have been constructed along different sections of the terrestrial margin of the SIS and the BIIS. In the late 1990s and early 2000s research focussed on the chronology of the Barents-Kara Ice Sheet and the north-eastern flank of the SIS. Ages implying glacier advances during the late Saalian, the Early and Middle Weichselian as well as the Late Weichselian were put forward (Forman, 1999; Larsen et al., 1999; Mangerud et al, 2001) and were integrated into an ice sheet history of northern Eurasia by Svendsen et al., (2004). Chronologies and deglaciation patterns based on or integrating the results from luminescence dating on different temporal and spatial scales were also put forward for the Vistula region in north-central Poland (Wysota et al., 2002, 2009), north-eastern Germany (Lüthgens and Böse, 2011), southern Jylland in Denmark (Houmark-Nielsen, 2007), Småland in southern Sweden (Alexanderson and Murray, 2007), southern Sweden and Bornholm (Kjær et al., 2006), the southwestern Baltic basin (Houmark-Nielsen and Kjær, 2003; Houmark-Nielsen, 2010), the Rondane area in east-central southern Norway (Bøe et al., 2007), northern Scotland (Duller et al., 1995), Buchan in north-eastern Scotland (Gemmell et al., 2007), and north Norfolk in the United Kingdom (Pawley et al., 2008).

However the reconstruction of the extent and timing of the SIS and BIIS behaviour throughout the last glacial cycles still has to be regarded as a work in progress, and OSL will play a major role in this reconstruction (Houmark-Nielsen, 2008). This is demonstrated by this volume which contains new results from OSL dating studies from Sweden (Alexanderson and Murray, 2012), central Norway (Johnsen et al., 2012), western Latvia (Saks et al., 2012) and southern Ireland (Ó Cofaigh et al., 2012). A central issue, that has become clear from existing studies, is the importance of crosschecking the results from different numerical dating methods with morpho-, bio- or sedimentostratigraphically based chronologies whenever possible (Houmark-Nielsen, 2008; Lüthgens and Böse, 2011; Alexanderson and Murray, 2012). It must be stressed that different dating methods date different processes in landscape development, as shown by Lüthgens and Böse (2012) in their analysis of OSL and surface exposure dating of the glaciogenic landscapes around Berlin. However, with an increasingly comprehensive record of numerical ages available, the reconstruction of ice sheet dynamics throughout the most recent glacial cycles will become more and more detailed and will most likely advance our understanding of the coupling of ice sheet behaviour and climate forcing factors (Lüthgens and Böse, 2012).

\section{History of north European glaciation 4.1 Offshore record}

\subsubsection{European continental margin}

The Northern European Continental Margin extends from Svalbard in the north to the Bay of Biscay in the south, lying adjacent to the coastlines of western Norway, Britain, Ireland and France (Sejrup et al., 2005). The shelf edge represents the maximum possible extent of grounded-ice onto the continental shelf during periods of low global sea-level. Iceberg calving occurred where the ice margins terminated within the marine environment - typically either within coastal areas or at the shelf edge during periods of maximum glaciation. Layers with IRD have been recognised throughout the North Atlantic region and provide a detailed long-term chronology of ice sheet behaviour. While much IRD relates to the Laurentide and Greenland ice sheets (Helmke et al., 2003), a growing body of literature documents the Plio-Pleistocene evolution of the main European ice sheets (Henrich and Baumann, 1994; Jansen et al., 2000; Knies et al., 2009; Scourse et al., 2009; Thierens et al., 2012).

Sedimentological, seismic and geomorphological evidence for glaciation is also preserved on the continental shelves and within a series of prograding submarine fans located at the continental margin. Submarine fans, commonly referred to as glacigenic fan complexes (GFCs), are mainly composed of glacigenic debris flows (GDFs) derived from the grounding-line of ice sheets, with thinner intervening clinoform sequences including glaciomarine and marine contourites, hemipelagites and sandy non-glacigenic mass flows (King et al., 1996; Vorren and Laberg, 1997; Knutz et al., 2002; Ó Cofaigh et al., 2003; Sejrup et al., 2005). GFCs document ice sheet expansions and oscillations onto 
the continental shelf and margin, and a growing body of literature has now identified a detailed record of glaciation associated with the European ice sheets that spans much of the Quaternary (Stoker, 1990, 1995, 1997; King et al., 1996; King et al., 1998; Dahlgren et al., 2005; Nygård et al., 2005; Sejrup et al., 2005).

IRD records from the Nordic Seas show a step-wise inception of large-scale glaciation adjacent to the North Atlantic region during the Plio-Pleistocene (Jansen et al., 2000; Knies et al., 2009). The first major influx of IRD, derived from the Greenland Ice Sheet, occurs at 3.3 Ma (Jansen et al., 2000) and is coincident with the first major global isotopic ice volume increase after $4 \mathrm{Ma}$ (Shackleton et al., 1995; Mudelsee and Raymo, 2005). Further IRD fluxes from Greenland are recognised between 3.12.9 Ma (Jansen et al., 2000). Both of these major IRD events have been recognised within the Eastern Equatorial Pacific within ODP 846 and suggest a strong Northern Hemisphere glacial signal (Shackleton et al., 1995). The extent of ice in northern Europe during the initial inception phase of Northern Hemisphere glaciation is unclear, although several studies have argued for the presence of local ice caps and mountain, valley/ fjord scale glaciation within parts of Scandinavia (Jansen and Sjøholm, 1991; Jansen et al., 2000; Flesche Kleiven et al., 2002) and the Barents Sea (Knies et al., 2009) regions.

The first major expansion of a European-based ice sheet equates to the deposition of IRD derived from the Scandinavian Ice Sheet in the Norwegian Sea (Krissek, 1989; Henrich and Baumann, 1994). This IRD influx has been timed at $2.74 \mathrm{Ma}$ (Jansen et al., 2000). It is synchronous with a marked IRD pulse from ice sheets in Greenland and North America (Shackleton et al., 1984; Chow et al., 1996; Jansen et al., 2000; Knies et al., 2002) and the first glaciation of the Barents Sea shelf (Knies et al., 2009). The inception of the BIIS is also considered to be coeval with this second up-scaling phase in Northern Hemisphere Glaciation (Sejrup et al., 2005; Lee et al., 2012; Thierens et al., 2012). Evidence consists of the first appearance of ice-rafted erratic clasts from northern Britain within cores from the upper Hebridean Slope (Stoker et al., 1994), plus IRD horizons from the Porcupine Seabight along the Irish margin (Thierens et al., 2012).

The period between c. 2.55-1.55 Ma is considered to be a period of reduced IRD activity within the North Atlantic (Fronval and Jansen, 1996), with only limited IRD input from the Greenland Ice Sheet (Jansen et al., 2000). However, evidence for the activity of the main European ice sheets at this time should not be under-stated. Records from the Irish margin demonstrate 16 major IRD events derived from the BIIS between c.2.6-1.7 Ma (Thierens et al., 2012), and regular expansions of continental ice into shelf areas can also be recognised from the mid-Norwegian Margin and the Barents Sea (Hölemann and Henrich, 1994; Wagner and Henrich, 1994; Knies et al., 2009).

The onset of large-scale shelf-edge glaciation in Europe occurs at c.1.1 Ma and is depicted by a sharp enhancement of glacial conditions throughout the Nordic Seas (Krissek, 1989; Henrich and Baumann, 1994; Helmke et al., 2003). Ice-rafted chalk micro-fossils identified within cores on the Vøring Plateaux are interpreted as evidence for the first large-scale glaciation of the Baltic/ eastern North Sea by the SIS (Henrich and Baumann, 1994; Hölemann and Henrich, 1994), and the first shelf-edge expansion of the Norwegian Channel Ice Stream (Sejrup et al., 1996). It marks a profound rampingup in the global scale of glaciation associated with the onset of the Mid-Pleistocene Transition (MPT) and the progressive change from $41 \mathrm{ka}$ obliquity to $100 \mathrm{ka}$ eccentricity climate forcing that occurred between 1.1-0.65 Ma (Clark et al., 2006).

Within the Bay of Biscay, Toucanne et al. (2009) recognise the first significant terrigenous input from the European ice sheets occurring between c. 970-939 ka (MIS 24-22), with further glacial inputs during MIS 16, 12, 10, 8, 6 and 2. Prior to MIS 12, the palaeogeography of the Southern North Sea and English Channel was markedly different, with Britain joined to continental Europe at the eastern end of the English Channel (Gibbard, 1988). Drainage from the Baltic Shield and northern Central Europe (the area glaciated by the SIS) was fed into the North Sea Basin precluding a SIS source for the glacially-derived material identified by Toucanne et al. (2009). Instead, provenance from ice sheets located over western Britain and Ireland appears more plausible for glaciation assigned to MIS 24, 22 and 16. Following glaciation and the breaching of the Strait of Dover during MIS 12, the North Sea and English Channel were connected and so it was possible during this and subsequent glaciations (i.e. MIS 10, 8, 6 and 2), for material from both the BIIS and SIS to be reworked via the Channel River System into the Bay of Biscay. 
The period from c.450 ka (MIS 12) to Termination 1 (MIS 2-1) is recognised by strong glacial and interglacial characteristics within the Nordic Seas (Henrich and Baumann, 1994) and the development of regular shelf-edge glaciations during cold stages. Much European research has focussed on direct marine evidence for glaciation located on the continental shelves and within GFCs (Sejrup et al., 2000; Nygård et al., 2005; Sejrup et al., 2005). Analogous with the development and collapse of the last Laurentide Ice Sheet, there is evidence for shelf-edge glaciation and deglaciation of the BIIS and SIS during the last glacial cycle (Knutz et al., 2001; Wilson and Austin, 2002; Peck et al., 2007; Peters et al., 2008; Scourse et al., 2009, Clark et al., 2012, Grousset et al., 2000). These papers identify a complex spatial and temporal pattern of maximum ice sheet extent associated with surging, collapse and active retreat of ice sheets at millennial time-scales similar to Dansgaard-Oeschger cycles (Wilson and Austin, 2002; Scourse et al., 2009) and driven by variations in the latitudinal position of the Polar Front (Scourse et al., 2009). The LGM associated with the BIIS and SIS as defined by their maximum extent on the continental shelf have been placed 29 and 24 ka (Scourse et al., 2009, Clark et al., 2012, O' Cofaigh et al., 2012 ) and 25 ka (Lekens et al., 2005) with later, local expansions.

\subsubsection{The North Sea region}

Widespread evidence of glaciation exists throughout the North Sea Basin including the Norwegian Channel. The earliest reported glacial incursions have been recognised by the presence of iceberg scours in 3D seismic data within the British (Graham, 2007; Graham et al., 2011) and Dutch (Kuhlmann and Wong, 2008) sectors. They are tentatively dated to around $1.8 \mathrm{Ma}$ and indicate the presence of British and Scandinavian ice within the shallower coastal margins of the North Sea (Graham, 2007; Graham et al., 2011; Kuhlmann and Wong, 2008). Lithological and palynological evidence also demonstrate the presence of ice in the Central North Sea during the 'Fedje Glaciation' (c. MIS 34, $1.1 \mathrm{Ma}$ ) (Sejrup et al., 1987; Sejrup et al., 1991; Ekman, 1998, 1999). This glaciation corresponds to the first known activation of the Norwegian Channel Ice Stream which drained the western sector of the Scandinavian ice sheet via the Norwegian Channel to the continental margin (Sejrup et al., 1995, 1996. 2000; King et al., 1996, 1998).

During the period around MIS 22-13 there is strong evidence for glaciation reaching the margins of the North Sea Basin although the precise timing of many of these events is unclear. Off eastern Scotland glaciomarine deposits have been identified within the Aberdeen Ground Formation that overlie the Bruhnes-Matuyama palaeomagnetic reversal (c. $0.78 \mathrm{Ma}$, MIS 19) (Stoker and Bent, 1985). They are considered to be stratigraphically equivalent to adjacent iceberg scours recognised within 3D seismic data (Graham, 2007; Graham et al., 2011) indicating possible glaciation during MIS 18 (Holmes, 2003; Graham, 2007 or within the 'Cromerian Complex' (Graham et al., 2011). Within the Southern North Sea, deposits that contain a glacigenic input have been identified from cores drilled on the Dogger Bank and are believed to be of early Middle Pleistocene age (Zagwijn, 1986; Laban and van der Meer, 2004).

MIS 12 corresponds to the first basin-wide expansion of British and Scandinavian ice into the North Sea Basin. This included the activation of the Norwegian Channel ice stream (King et al., 1998; Sejrup et al., 2000), widespread expansion of ice into more southern parts of the basin (Ehlers et al., 1984; Cameron et al., 1987; Carr, 2004; Laban and van der Meer, 2004) and extensive generation of subglacial tunnel valleys parts of the British, Dutch and Danish sectors (Wingfield, 1990; Laban, 1995; Huuse and Lykke-Andersen, 2000; Kluiving et al., 2003; Praeg, 2003; Stewart and Lonergan, 2011).

Several additional Middle Pleistocene glacial episodes have been identified within the North Sea. Stewart and Lonergan (2011) recognise seven distinctive generations of cross-cutting subglacial tunnel valley features and attribute them to successive glaciations between MIS 12 and 2. Seismicallydefined units bound by glacial erosion surfaces in the Norwegian Channel (Sejrup et al., 2003) and a borehole from the Jæren lowlands of western Norway that records a MIS 6 till, provide evidence for glaciation of the Norwegian Channel ice stream (Janocko et al., 1997). To the south, within the Dutch sector, Beets et al. (2005) have identified a MIS 8 till based upon AAR dating of mollusc shells and foraminifera tests although previously this till was attributed to the younger 'Saalian' (MIS 6) glaciation (Ehlers, 1990; Carr, 2004). The precise configuration of the Scandinavian and British ice sheets in the North Sea during the Saalian has been debated extensively (Long et al., 1988; Rappol et al., 1989; Laban, 1995; Carr, 2004). In the Southern North Sea, the presence of the Cleaver Bank Formation suggests that ice-free glaciolacustrine conditions prevailed across much of the region at this time (Rappol et al., 1989; Cameron et al., 1992; Laban, 1995; Busschers et al., 2008; Davies et al., 2012). By contrast, on both the UK and Norwegian sides of the Central North Sea there is strong evidence for 
grounded ice although whether the two ice sheets were confluent is not known (Stoker et al., 1985; Sejrup et al., 2003; Graham, 2007; Davies et al., 2012).

The North Sea was glaciated for a final time during the Late Weichselian (MIS 2). Well-developed seismic, geomorphological and sedimentological evidence now exists for the coalescence of both the Scandinavian and British ice sheets in the northern North Sea (Carr et al., 2006; Bradwell et al., 2007; Graham et al., 2007, 2009; Bradwell et al., 2008c) (Figure 3) with ice reaching its maximum extent at the continental margin around 29 ka BP (Sejrup et al., 2009). Separation of the two ice sheets is considered to have occurred by 25 ka BP (Sejrup et al., 1994; Bradwell et al., 2008c; Sejrup et al., 2009, Clark et al., 2012) with numerous ice-marginal oscillations occurring during retreat (Bradwell et al., 2008c, Clark et al., 2012).

\subsection{Terrestrial evidence}

\subsubsection{Pre MIS 12 Glaciations}

There is only limited terrestrial evidence for glaciation in northern Europe prior to MIS 12 (Ehlers and Gibbard, 2007). Debate surrounds whether this is an artefact of limited ice sheet and glacier activity during this time-interval; whether glaciations were much smaller in extent with evidence being removed by later Pleistocene glaciations; or simply, that evidence of glaciation is more subtle, has not been discovered or has been mis-interpreted. Within Britain, the longest records of Early and early Middle Pleistocene environmental change are the terrace record of the Ancestral Thames, and shallow marine and coastal 'Crag' deposits of the North Sea in East Anglia (Rose et al., 2001). Both the Ancestral Thames, (Hey and Brenchley, 1977; Whiteman, 1992; Whiteman and Rose, 1992; Rose et al., 1999; Rose et al., 2010) and 'Crag' (Larkin et al., 2011) deposits contain large over-sized erratics believed to be derived from glaciations in highland areas of Britain, and in the case of the latter, southern Norway. However, the sequences are highly fragmentary in nature and possess limited datable material so developing a reliable chronology has proved problematic. Modelling of patterns of river terrace development and correlation with biostratigraphic evidence led Westaway et al. (2002) to suggest tentatively, that glaciations within the Thames catchment occurred during MIS $68,62-54,54-36,36-32,22,20,18$ and 16 , although these ages have subsequently been changed (Westaway, 2009).

Elsewhere within eastern England, a number of tills and outwash deposits (Happisburgh Formation) previously assigned to the Anglian Glaciation (MIS 12), have been re-interpreted as the product of an earlier glaciation, possibly equivalent to MIS 16 , based upon correlation with the terrace record of the pre-Anglian Bytham River (Lee et al., 2004). This age interpretation is not supported by AAR dating or biostratigraphy which suggests a conventional MIS 12 age for the deposits (Preece et al., 2009, Rose, 2009).

Within the Netherlands, there are several lines of discrete evidence for the existence of pre-MIS 12 glaciations (Lee et al., 2012). The Hattem Bed Complex is a fluvial deposit that contains numerous erratics of Fennoscandian origin (Zandstra, 1983), believed to represent the first extensive glaciation of the Baltic area and termination of the Baltic River System (Overeem et al., 2002) during the Menapian Stage (MIS 34, c.1.1 Ma) (Zandstra, 1971; Ehlers and Gibbard, 2007). Superseding the Hattem Bed Complex are a series of glaciofluvial facies called the Weerdinge Member (Westerhoff et al., 2003), and these are assigned to 'Cromerian C Glaciation' of the 'Cromerian Complex' (Ruegg and Zandstra, 1977). Amongst the derived lithological components are heavy minerals and erratics of glacial origin from southern Norway and the eastern Baltic (Zandstra, 1971, 1983; Ruegg and Zandstra, 1977; Bosch, 1990; Skupin et al., 1993).

In Eastern Europe, evidence for a pre-MIS 12 expansion of the SIS is present within the Oka and Don Lowlands and the eastern margins of the Central Russian Upland in European Russia (Molodkov and Bolikhovskaya, 2006), and southern Poland (Gozhik et al, in press). The earliest of these glaciations corresponds to the maximum extent of the SIS in European Russia and is referred to as the Don Glaciation (Astakhov, 2004a, b) and is characterised by tills, glaciofluvial deposits and morainic landforms (Molodkov and Bolikhovskaya, 2006). It is separated from the main MIS 12 (Oka) Dneiper till by two separate horizons containing interglacial deposits and palaeosols and has therefore been assigned to MIS 16 (Velichko and Faustova, 1986; Velichko et al., 2004). Interestingly, the Oka Glaciation is considered to span the whole of the period from MIS 14 to MIS 12 with sub-arctic conditions prevailing throughout (Molodkov and Bolikhovskaya, 2006). 
Böse, M., Lüthgens, C., Lee, J.R. \& Rose, J. 2012. Quaternary Glaciations of northern Europe. Quaternary Science Reviews 44, 1-25. [Pre-proof accepted manuscript]

\subsubsection{Late Middle Pleistocene Glaciations (MIS 12-6) \\ - $\quad$ the Elsterian issue (MIS 12 or 10), correlation between the UK and continent \\ - $\quad$ the Saalian glaciation}

Although there has been considerable progress with our understanding of pre-MIS 12 glaciations offshore (see above) and a vast increase in our understanding of glacier behaviours during the Last Glaciation (see below), both primarily as a result of the development of new techniques, our understanding of the glacial history of the land areas of northern Europe and the British Isles during the Middle Pleistocene and possibly earlier (MIS has made little progress, and much confusion and debate remains (Rose, 2009).

With respect to the SIS the history of glaciation over this period is still not fully understood. In contrast to the eastern part of Poland, where sediments attributed to an Early Pleistocene glaciation and to a glaciation within the Cromerian complex (approximately between MIS 21 to 13) (Marks, 2011). Only two pre-Weichselian glaciations are documented in Germany: the Elsterian - corresponding to the Sanian 2 in Poland - and the Saalian glaciation (Eissmann, 1995; Litt et al., 2008). The existence of pre-Elsterian glacial sediments has been discussed sporadically (Vinx et al., 1997), but conclusive evidence is still awaited (Litt et al. 2007).

The first definitely accepted ice advances to northern Germany belong to the Elsterian glaciation, which is attributed to MIS 12 (Ehlers et al., 2011). In the north, Elsterian deposits directly overlie Tertiary sediments across wide areas. The base of the Elsterian glacial sequence in northern Germany, as well as in adjacent areas, shows deep buried valleys filled with Elsterian sediments of various types such as glacioliminic silts and clays, glaciofluvial sands and gravels and patches of till (cf. contributions by Kuster and Meyer, 1979; Grube, 1979; Hinsch, 1979; Wiederhold, 2009). Further south, the Elsterian glacial sequences overlie fluvial deposits of cold and warm phases (Eissmann, 1997, 2002; Litt et al., 2008).

Because landscape elements of the Elsterian glaciation are not well preserved, its maximum extent has been reconstructed from sediments (Eissmann, 2002). At the border of the Mittelgebirge (central German uplands), where the Elsterian glaciation extended further south than the Saalian, it is identified by the so-called "Feuersteinlinie" (flint line) representing the furthest transport of Nordic material (Wagenbreth and Steiner, 1990). The ice abutted against the mountains of the region up to elevations of 400 to $500 \mathrm{~m}$ asl.

Two till layers of Elsterian age, separated by meltwater deposits, are common, but they cannot be correlated over longer distances. Therefore it is not possible to infer any climatic changes during the Elsterian glaciation.

The westward extent can be traced by tills to the area between Elbe and Weser. Further west and southwest, Elsterian tills are almost absent, and only the distribution of Nordic rock material, often redeposited by fluvial processes, gives evidence of ice transport (Caspers et al., 1995).

Sediment sequences of the Elsterian glaciation as well as the following Saalian complex have been studied most comprehensively in the open-cast brown coal mines of Saxony and Thuringia (Eissmann, 2002). A stratigraphy with local names was given by Eissmann (2002) according to the detailed descriptions of the outcrops at these localities.

In northern Germany, the Saalian complex consists of a long period without glaciation. According to 230Th/U dates which attribute the Holsteinian to MIS 9, the non-glaciated time of the Saalian comprises MIS 8 and 7 (Litt et al., 2007; Urban et al., 2011, Lang et al., 2012). Traces of an early Saalian glaciation have been found in eastern Poland, but the extent of this glaciation further west in Poland is still unknown (Marks, 2011). The widespread fluvial terrace deposits, periglacial sediments and glaciolacustrine deposits preserved in sections and borehole records, which constitute the evidence for this period of time, are documented in Eissmannn (2002) and Lang et al. (2012).

Traditionally the Saalian glaciation is subdivided into the Drenthe Phase (van der Vlerk and Florschütz, 1950) and the Warthe Phase (Woldstedt, 1954) which was less extensive. These 
correspond to the Odra and Wartanian glaciations in Poland. Local stratigraphies exist, but are still not well correlated (Ehlers et al., 2011).

In northwest Germany the maximum extent of the Saalian glaciation exceeds the Elsterian ice advance controlling the lower Rhine system and forming distinct push moraines in the Netherlands. The ice of the maximum extent also abutted against the mountains of Lower Saxony, creating icedammed lakes. Ice marginal drainage developed during the process of ice wastage and during later sub-phases (Winsemann, 2009).

The Middle Saalian Glaciation is attributed to the Warthe I sub-phase (Ehlers et al., 2011). Before this readvance, the SIS melted back at least to the Baltic Sea depression. The maximum extent to the west reached the area between Elbe and Weser; further southeast and east, the position of the ice margin is not clear as the sediments overlap with the younger Saalian glacial deposits in the areas of Altmark and Fläming. In general, major oscillations of the ice margin are documented, and lithostratigraphy shows a change of the ice flow from a more northerly to more north-easterly directions. The Aller-Weser ice marginal spillway was a major drainage system to the North Sea basin.

The Warthe II ice advance, also called Upper Saalian glaciation, is characterised by distinct ice marginal features including end moraines and outwash plains and ice marginal valleys. This subphase was of minor extent, crossing the river Elbe to the west. Further southeast and in easterly directions, the correlation of the distinct landforms, mainly composed of several push moraines, is still under discussion. Correlations rely on lithostratigraphic arguments as the Warthanian ice advance has a widespread east Baltic till facies. In Poland very distinct push moraines are also attributed to the Wartanian glaciation; here they are considered to represent a huge oscillation of the SIS during MIS 6 (Marks, 2011).

Though the Saalian glacial phases have not been dated directly so far, some IR-RL (InfraredRadiofluorescence) data give age estimates ranging between $310 \mathrm{ka}$ and $150 \mathrm{ka}$ from underlying fluvial complexes. This implies a quite long phase of cold-climate during the Lower Saalian - about $160 \mathrm{ka}$ - preceding the Upper Saalian ice advances (Krbetschek et al., 2008).

Older, probably less reliable TL analyses from glaciofluvial deposits in Schleswig-Holstein have provided ages of between $150 \mathrm{ka}$ and $100 \mathrm{ka}$, (Marks et al., 1995). OSL ages from this region range from $164 \pm 27 \mathrm{ka}$ to $199 \pm 27 \mathrm{ka}$ (Preusser, 1999). OSL age estimates from sediments north of the Fläming and the Baruth spillway, deposited during a Warthe retreat stage, gave ages clustering around 150 ka to 130 ka (Lüthgens et al., 2010).

The Saalian glaciations occurred in MIS 6 and therefore lasted - including all their minor and major oscillations - about $20 \mathrm{ka}$.

The Netherlands possesses extensive evidence for late Middle Pleistocene glaciation during both the Elsterian and Saalian. Evidence for the Elsterian glaciation occurs throughout the northern part of the Netherlands and comprises widespread subglacial tunnel-valley systems, associated glaciolacustrine sediments (Peelo Formation) and occasional bodies of till (Zagwijn, 1989; Laban, 1995; Laban and van der Meer, 2011). The specific timing of the Elsterian glaciation is an increasingly controversial issue (Lee et al., 2012) with opinions sharply divided between a conventional MIS 12 age (Zagwijn, 1996; Laban and van der Meer, 2011) or a younger MIS 10 age (Vandenberghe, 2000; Meijer and Cleveringa, 2009). Debate is centred upon the application of AAR dates to the Dutch sequence (Meijer and Cleveringa, 2009), and the precise timing and transport history relating to the input of volcanic tuffas from the Eifel volcanic region into the Rhine catchment (Boenigk and Frechen, 2006; Litt et al., 2008). The latter represents a key chronostratigraphic marker horizon with the Dutch Middle Pleistocene succession. A second late Middle Pleistocene glaciation, the Saalian-Drenthe glaciation, occurred throughout much of the Netherlands. Evidence takes the form of subglacial tunnel-valleys, tills, outwash deposits, streamlined drumlinoid bedforms and large terminal moraine complexes (Laban, 1995; Bakker, 2004; Laban and van der Meer, 2004, 2011). Deposits relating to this glaciation have recently been dated by OSL to MIS 6 (Busschers et al., 2008) supporting earlier views of its age (Laban, 1995; Laban and van der Meer, 2004). The pattern of glaciation during the Drenthe is characterised by an early ice advance towards the southwest, followed by a brief standstill, and subsequent southwards (from the northwest then northeast) re-advance which formed the main Drenthe terminal moraine complex (Rappol, 1987; Kluiving et al., 1991). Within the Southern North 
Sea extensive glaciolacustrine conditions prevailed contributing to the polyphase formation and incision of the Straits of Dover (Busschers et al., 2008).

The issue of the glacial history of the British Isles during the late Middle Pleistocene has stimulated much research and generated much controversy (Clark et al., 2004; Gibbard et al., 2008, Rose, 2009, Davies et al., 2012), primarily because of the abundance of glacial materials and the absence of intervening non-glacial deposits or soils, especially deposits or soils that can be dated with any confidence. Traditional approaches for dating the glaciations using pollen biostratigraphy have been demonstrated to be flawed (Seppä and Bennett, 2003). The evidence for glaciations of this age is to be found primarily in eastern England, especially East Anglia, with fragmentary evidence in Scotland and Ireland. The main evidence are summarised in Bowen et al. (1986) and in Knight et al. (2004). Initially, the 'modern' model for glaciation over this period consisted of two lowland glaciations (Mitchell et al., 1973): an earlier Anglian Glaciation equated with the Elsterian of Europe and a Wolstonian Glaciation equated with the Saalian (Shotton, 1976, 1983; Straw, 1979) (Figure 4A) and these are cited in the most recent stratigraphic scheme for the British Quaternary (Bowen, 1999). The Anglian is defined by a stratotype at Corton near Lowestoft in East Anglia (Pointon, 1978) and the Wolstonian by a stratotype at Wolston near Coventry in midland England (Shotton, 1976, 1983) (Figure 4A).

Subsequently, following a detailed spatial analysis of the sedimentary petrography of the tills in midland and eastern England (Perrin et al., 1979), this scheme was revised to a one-glaciation model, with the glaciation attributed to the Anglian Stage (Figure 4B). Critically, the glaciogenic deposits upon which the Wolstonian Glaciation was identified were shown in Perrin et al. (1979) to be part of the same association of deposits as those considered to be of Anglian age further east, and the associated Wolstonian fluviatile deposits that underlie the glaciogenic sediment have been shown to be pre-Anglian in age (Rose, 1987, 1994) rather than younger than Anglian as proposed by Shotton $(1976,1983)$. Traces of other late Middle Pleistocene glaciations were still identified at specific localities in east Lincolnshire, Yorkshire and Durham (Catt and Penny, 1966; Davies et al., 2012), and reference to these sites and their significance can be found in Bowen et al. (1986) which also allocates the glaciations to geochronometric ages and Marine Isotope Stages. Thus the most extensive glaciation of Britain was considered to have occurred during MIS 12, and subsequent late Middle Pleistocene glaciations are interpreted as occurring during MIS 8 (in south Wales) in the west Midlands and eastern England, reaching positions just beyond the limit of the Last Glaciation (Bowen et al., 1986) (Figure 4B). This model has persisted to the present time in some publications (Gibbard in Clark et al. 2004; Gibbard and Clark, 2011), albeit with modifications around the limit of the younger of the late Middle Pleistocene glaciation (Gibbard et al., 2008; Gibbard and Clark, 2011) (Figure 4C).

The concept that the glaciogenic deposits of eastern and midland England were formed by one glacial event (Perrin et al. 1979) is well substantiated. This event has been be dated to MIS 12 by reference to dated materials (AAR, U-series, ESR) that overlie or underlie the glaciogenic sediments (Bowen et al., 1986; Bowen, 1999, Rowe et al., 1999; Grün and Schwarcz, 2002; Preece et al., 2009; Penkman et al., 2011), and by direct dating of the glaciogenic material using OSL (Pawley et al., 2008, 2010). The MIS 12 age allocation is reinforced by the fact that the glacial deposits at their southern limit can be correlated with terraces of the River Thames that have been dated by a number of geochronometric methods (Bridgland, 1994; Bridgland et al., 2004; Penkman et al., 2011). In summary, there is substantial evidence that the most extensive late Middle Pleistocene glaciation in the British Isles occurred during MIS 12 and reached a southern limit in the region of the River Thames.

Nevertheless, an alternative scheme has been proposed as a result of detailed geological mapping in East Anglia (Figure 4D) (Hamblin et al., 2000; 2005, Rose, 2009). This scheme proposes that in addition to the MIS 12 glaciation described above, extensive glaciation occurred in midland England and East Anglia during MIS 10. This glaciation is dated by a U-series age on overlying peat deposits (Rowe et al., 1999) and correlation of the glacial deposits with the terrace deposits of the Middle Thames near Oxford (Sumbler, 1995, 2001), although this correlation has since been challenged (Westaway, 2011). The deposits of this glaciation are lithologically distinctive and can be traced above those of the Anglian Glaciation in north East Anglia, where they are sandy tills overlying chalky tills, and the east and west Midlands where they are chalky tills overlying chalk-free tills, but in central and southern east Anglia the tills of both MIS 12 and MIS 10 have a similar lithological composition and a limit for the MIS 10 event has yet to be identified. The same programme of geological mapping also concluded that a MIS 6 glaciation reached the north coast of East Anglia where it deposited a 
distinctive lithofacies with Scandinavian erratics and produced distinctive ice marginal landforms such as push-moraines and outwash fans with ice-contact slopes, similar to those formed during MIS 6 glaciations further east in the Netherlands and north Germany (Hamblin et al., 2000; 2005, Rose 2009). This ice limit is linked to a proposal for a MIS 6 glaciation identified by outwash sediments in northwest Norfolk (Gibbard et al., 1992, 2009; Gibbard and Clark, 2011). The age for this glacial event is based palaeosol microstratigraphy from an overlying fossil soil (Lewis and Rose, 1999)) and the freshness of the topography by comparison with northern Europe. Attempts to ascertain the age of this glaciation using OSL have yielded results that support an MIS 6 age in places (Pawley et al., 2008), but not in others (Pawley et al., 2008) - clearly more work is needed.

Finally, White et al. (2010) have proposed that a MIS 8 glaciation has extended across the region of the middle Trent valley, based on the relationship of the glacial deposits with the associated river terraces. This proposal adds to the complexity of the story of late Middle Pleistocene glaciation in Britain.

Attempts to link the late Middle Pleistocene glaciations on the British Isles with equivalent glaciations on continental Europe have made little progress, although hopefully OSL studies will provide a way forward. Oele and Schuttenhelm (1979) traced the evidence for the MIS 6 (Drenthe) glaciation of the Netherlands across the North Sea and linked this to a site with post MIS 12 and pre MIS 2 glacial deposits in Lincolnshire and this is the basis of the limits drawn in Bowen et al. (1986). Subsequently this ice limit has been moved southward to accommodate the evidence from northwest Norfolk and this new limit is used in Gibbard and Clark (2012). In this case a MIS 6 ice limit is proposed on both sides of the North Sea and the glacial limit is characterised in both areas by traces of constructional landforms (Rose, 2009). However, correlation of earlier, late Middle Pleistocene glaciations is far from resolved and the earlier assumptions that the Anglian of Britain is equivalent to the Elsterian of the continent is far from sure, with an age of MIS 12 accepted with some confidence in Britain and ages of MIS 12 and 10 being accepted in the Netherlands (MIS 12 age, Zagwijn (1996); Laban and van der Meer (2011), MIS 10 age (Vandenberghe (2000); Meijer and Cleveringa, (2009) (see above). Clearly more evidence is required before correlation between Britain and the Netherlands can be established with any confidence.

\subsubsection{Late Pleistocene Glaciations of the British Isles and northern Europe (MIS 4-2)}

The Late Pleistocene, with its lower limit at the base of MIS 5e, the onset of the Eemian (Ipswichian, Mikulinian) Interglacial includes the last glacial cycle, MIS 2 being the uppermost part (Cohen and Gibbard 2011). In continental Europe, the last glaciation is called the Weichselian or Vistulian Glaciation, the Valdai Glaciation when referring to the Russian plain and the Devensian Glaciation in Britain.

Evidence for Late Pleistocene glaciation prior to MIS is still patchy, and although several of the papers in the volume present a case for a MIS 4 or 3 glaciation, glacier flow directions are not known with confidence and glacier limits can only be estimated (Saks et al., 2012; Marks, 2012; Thierens et al., 2012). However, with new dating methods (OSL, cosmogenic radionuclide exposure dating) that extend into the time range, the discussion about an earlier Weichselian ice advance has again been put on the agenda. The Ristinge Klint till in Denmark, which was assumed to represent an ice advance along the line of the Baltic Sea depression and therefore had a southeasterly flow direction as shown by its petrographical composition and the incorporation of Eemian foraminifera (Petersen 1985, Houmark-Nielsen, 2004, 2010) is attributed to MIS 3. Its extent is difficult to define because end moraines are absent. According to Houmark-Nielsen (2010), it may have reached even farther than the classical LGM in southern Denmark and the very northern part of Germany. A first ice advance to northeastern Germany during early or middle Weichselian time, although still undated today, has also been discussed by Rühberg et al. (1995), but it's possible extent has not yet been reconstructed. Cosmogenic radionuclide ages are used to infer a similar MIS 3 glaciation in the southern Baltic region, Poland and Lithuania, and the possible extent of these glacier expansions are shown in Marks (2012, Figure 8a). There have been some proposals for MIS 4 or MIS 3 glaciation in the area of the BIIS, based on either AAR determinations (Bowen et al. 1985) or AAR and cosmogenic radionuclide exposure dates (Bowen et al., 2002), but hitherto none of the evidence cited has been replicated and there are no glacial deposits that can be attributed, by further analysis, to these periods.

Typically, the topography of glacial terrain formed during the Late Pleistocene is characterized by lakes, dead ice hollows, meltwater valleys and channels, outwash cones and plains as well as ice 
marginal forms such as push moraines, depositional end moraines or the proximal parts of outwash sediments, traditionally identified by morphostratigraphic methods. However this topography is not universal with respect to the BIIS, where an outer zone (that beyond the South Ireland End Moraine of Ó Cofaigh et al. (2012b)) and beyond the constructional topography of Vale of York and Cheshire Plain in England (Clark et al., 2012) lack these characteristically 'fresh' glaciogenic landforms. In the continental part of northern Europe and the lowlands of Britain and Ireland, an extended belt of landforms composed of glacial deposits dominates the topography. Erosional landforms like the present-day fjords and glacially eroded troughs prevail only at the western fringe of the former SIS and in the mountain regions of Scotland, Ireland, Wales and northwest England. The general southern and southwestern maximum extent of the Weichselian ice sheet is defined by means of morphostratigraphy on the maps of Woldstedt $(1925,1935)$ and Liedtke $(1975)$, for example in the northern European mainland and those of Charlesworth (1955) and Clark (2012) in Britain. Minor local variations are discussed in some areas, mainly when end moraines are absent and dead ice hollows in the landscape suggest a "super maximum" ice advance, possibly equivalent to the more subdued terrain beyond the constructional landforms in lowland Britain and Ireland. The likely reason for the greater degradation and removal of lakes from this region in the area of the BIIS is that the more maritime climate of Ireland and Britain has resulted in more moisture in the geomorphic system and accelerated rates of landscape degradation relative to the more continental area of mainland northern Europe.

Where constructional landforms do exist, and they can be mapped to identify ice marginal positions of the last glaciation, a morphostratigraphically based chronology has been established. With respect to northern Europe the chronology of the ice advances during the Weichselian glaciation, as provided by Kozarski (1995) has remained almost unchanged for almost a decade. The general timing of the Last Glacial Maximum (LGM) in terms of maximum ice sheet extent was correlated with MIS 2, indicating the coldest phase of the last glacial cycle. This timing was based on interpretations of radiocarbon dates from under- or overlying organic sediments, but never on dates of the glacial sediments themselves. This lithostratigraphy yielded different results even in neighbouring countries. In Germany, the Frankfurt ice marginal position is considered to be a recessional position north of the Brandenburg maximum phase and lacks an independent till (Cepek 1965). According to morphostratigraphy, however, the equivalent Poznan phase in Poland is considered a readvance, even exceeding the margin of the Leszno (Brandenburg) phase (Marks 2012) in some areas; in eastern Poland the Poznań phase merges with the Leszno (Brandenburg) ice margin. At the northeastern fringe of the SIS, in western Siberia, the LGM in the sense of the farthest ice advance of the Nordic glaciation has been shown to be younger than at the southern fringe (Svendsen et al. 2004).

Using the information provided in the papers of this volume a small scale map of the ice marginal positions, in both northern Europe and Britain and Ireland is presented (Figure 5), supported by Table 1 which places together the likely MIS 2 ice limits and the subsequent recessional stages.

When this information is linked to the many new ages that actually date the glacial sediments, the pattern that emerges is one of immense complexity, whereby the ice sheets are dominated by asynchronous ice-streams, from different source areas. The reasons for this are self-evident following research on glacier behaviour that has taken place over the last several decades (Benn and Evans, 2010; Stokes and Clark, 2001; Boulton, 2001, 2009; Hubbard, 2009). The factors forcing the icestream behaviour range from shifts in the climatic zones such as the Polar Front, the sequential development and loss of precipitation shadow, variations in the deformability of the glacier bed as a result of changes in lithology, changes in the temperature of the glacier bed and associated subglacial palaeohydrology, and changes in the level of the adjacent seas. Nevertheless it would appear that the most recent expansion of the SIS and BIIS reached limits between $29 \mathrm{ka}$ and $19 \mathrm{ka}$ and that even within this time period the ice sheets experienced major marginal retreats and subsequent expansions (Johnsen et al., 2012, Clark et al., 2012). This scenario is supported by the modelling exercises of Hubbard et al. (2009) which tunes the development of the BIIS to the temperature record from the NGRIP oxygen isotope curve (http://www.ncdc.noaa.gov/paleo/icecore/greenland/ngrip/ngripdata.html) and the SPECMAP sea-level reconstruction (Thompson and Goldstein, 2006). Even though this publication retains many results that do not match the ground truth, the principles behind the exercise are basic and sound and illustrate with wonderful clarity the temporal and glaciological dynamics of the BIIS. 
The timing of the wastage of the SIIS and BIIS also needs much new work. It has long been known that the SIS remained in Scandinavia through the Lateglacial climatic oscillation of the Bølling/ Allerød Interstadial and the Younger Dryas cold period, so that ice remained in the source areas of that ice sheet until the period formally known as the Holocene, but in Britain and Ireland the long-held view that ice had melted away before the Bølling/ Allerød Interstadial (Windermere Interstadial of Britain/ Nehanagan Interstadial of Ireland), has recently been challenged for northwestern Scotland. Wastage of the ice sheets back to ultimate deglaciation appears to have occurred at a variety of rates reflecting the complexity of glacier forcing outlined above and in Clark et al. (2012), to the extent that it seems almost impossible to give a generalisation. With the type and resolution of dating now available it is likely that in the future, timing of ice wastage will be related to individual ice stream.

\subsubsection{The meaning of LGM in the context of the SIS and BIIS}

At the present time the question of what LGM really means is an important issue. It is clear that as a result of recent studies, of ice marginal positions that have long been considered to be synchronous, are recognised as time transgressive (Figure 5). Is the LGM time transgressive in terrestrial areas when defined according to geomorphological ice marginal features, or is it defined by the maximum ice volume as identified by the marine oxygen isotope stages? In either situation there is no case for its use as a formal term, but the term does have considerable value as an informal indicator of ice expansion during MIS 2. Thus, the term LGM has to be defined, even if only loosely, either as a timeslice for the maximum ice volume or as representing the local maximum ice sheet extent.

\section{Conclusions}

- This volume includes a number of papers that outline recent work on Quaternary glaciations of northern Europe, including the British Isles and Ireland and the offshore regions.

- High quality geomorphological mapping using newly available DEM imagery has provided data both on the terrestrial areas and on parts of the sea-bed that allow the derivation of a morphostratigraphy, that has hitherto been unachievable.

- High quality OSL and cosmogenic radionuclide dating of glaciogenic sediments, along with AMS radiocarbon ages of materials that can constrain glaciation have enabled a revolution to take place in the understanding of the MIS 2 glaciation, particularly with respect to the dating of the maximum extent of this glaciation in different parts of the SIS and BIIS, and the wastage of these ice sheets.

- The applications and strengths and weakness of both OSL and cosmogenic radionuclide dating are examined, with a clear statement that an OSL will give a maximum age and an exposure date will give a minimum age, so that dates from these methods on the same glaciogenic unit should not be expected to be the same.

- The results of these new dating exercises reveal a hitherto un-realised complexity of glacier behaviour with distinctive patterns of advance and retreat for the various ice streams that comprise much for glacier bodies.

- As a consequence of the complexity of ice stream behaviour the timing of maximum expansion of the SIS and BIIS varies from about $29 \mathrm{ka}$ to $19 \mathrm{ka}$, and the details of this variation is given in Figure 5 and the respective papers.

- The retreat stages/ sub-stages/ phases/moraines mapped around the southern margin of the SIS and cannot be related to any specific periods of time and are diachronous - correlation is therefore an unrealistic concept.

- Hitherto, it is difficult to derive a general explanation as to why certain ice-streams advance before others, but the style of expansion and retreat derived from the studies in this paper is in line with the style and rates of advance and retreat modelled by tuning glacier behaviour over at least part of the region to temperature as proxied by the NGRIP ice core and the SPECMAP pattern of sea-level variation.

- Evidence of the long-term glacial history of the region is presented in the form of IRD from the Challenger coral carbonate mound off the Irish northeast Atlantic continental margin. Synthesis of evidence from whole offshore region indicates prolonged IRD activity that occurs discontinuously through much of the Quaternary.

- The long term records indicate a step change in the glacial history of the region with glaciation first recorded around 2.7 Ma, after which there is evidence for local glaciation in the mountain regions until around 1.1 Ma. Lowland glaciation is first identified as occurring after $1.1 \mathrm{Ma}$, and 
the first substantial glacial deposits are associated with glaciation that occurred after around 500 ka (either MIS 16 or 12).

- The pattern and history of glaciation northern Europe and the British Isles between MIS 12 and 4 is very complicated with an absence of agreement between different regions (Britain, Netherlands, Germany, Poland, Russia). While this may well reflect a different glacial history in these different regions, as exemplified by the history of the different ice streams in MIS 2, the quality of the chronological control is, as yet, not sufficient to make any definitive statement.

- The maximum expansion of glaciation in Poland is MIS 16 with expansion of the SIS into the lowland region during MIS 12, 10, 6, 4 and 3. In northern Germany expansion of the SIS took place in MIS 12 and 6, 4 and 3 with possible evidence for an expansion in MIS 8, while the maximum expansion of glaciers over the Netherlands is currently attributed to MIS 10 and 6 with ice reaching the Netherlands offshore region in MIS 8. Evidence for glaciers reaching the lowland of Britain during this time period is highly controversial with what is considered to be strong evidence for glaciation in MIS 12 and 6, debatable evidence in MIS 10 and tentative evidence in MIS 8.

\section{Acknowledgements.}

The editors of this volume would like to thank all those who participated in the Berlin Workshop and to Tom Bradwell, Geoffrey Boulton and Stephen Livingstone for allowing us to use figures previously published in their papers. Phil Wilby and Jon Ford are kindly thanked for their constructive comments on an early draft of the manuscript. We would also like to thank Debbie Barratt of Elsevier who handled this volume so professionally and patiently. JRL and JR publish with the permission of the Executive Director of the British Geological Survey (NERC). 


\section{References}

Aber, J.S., Croot, D.G., Fenton, M.M. 1989. Glacitectonic Landforms and Structures. Kluwer, Dordrecht.

Aitken, M.J., Tite, M.S., Reid, J. 1964. Thermoluminescent dating of ancient ceramics. Nature 202, 1032-1033.

Alexanderson, H., Murray, A.S., 2007. Was southern Sweden ice free at 19-25 ka, or were the post LGM glacifluval sediments incompletely bleached?. Quaternary Geochronology 2, 229-236.

Alexanderson, H., Murray, A.S. 2012. Problems and potential of OSL dating Weichselian and Holocene sediments in Sweden. Quaternary Science Reviews 34

Astakhov, V. 2004a. Middle Pleistocene glaciations of the Russian North. Quaternary Science Reviews 23, 1285-1311.

Astakhov, V., 2004b. Pleistocene ice limits in the Russian northern lowlands, In: Ehlers, J., Gibbard, P.L. (Eds.), Developments in Quaternary Science. Elsevier, pp. 309-319.

Bakker, M.A.J., 2004. The internal structure of Pleistocene push moraines: a multidisciplinary approach with emphasis on ground-penetrating radar. Unpublished PhD thesis, Queen Mary, University of London.

Ballantyne, C.K. 2002. Paraglacial geomorphology. Quaternary Science Reviews 21, 19352017.

Beets, D.J., Meijer, T., Beets, C.J., Cleveringa, P., Laban, C., van der Spek, A.J. 2005. Evidence for a Middle Pleistocene glaciation of MIS 8 age in the southern North Sea. Quaternary International 133-134, 7-19.

Boenigk, W., Frechen, M., 2006. The Pliocene and Quaternary fluvial archives of the Rhine system. Quaternary Science Reviews 25, 550-574.

Benn, D.I., Evans, D.J.A, 1996. The interpretation and classification of subglacially-deformed materials. Quaternary Science Reviews 15, 23-52.

Benn, D.I., Evans, D.J.A. 2010. Glaciers and Glaciation. Hodder Education, London.

Bernhardi, A. 1832. Wie kamen die aus dem Norden stammenden Felsbruchstücke und Geschiebe, welche man in Norddeutschland und den benachbarten Ländern findet, an ihre gegenwärtigen Fundorte?. Jahrbuch für Mineralogie, Geognosie, Geologie und Petrefaktenkunde 3, 257-267, Stuttgart.

Bitinas, A. 2012. New insights into the last deglaciation of the south-eastern flank of the Scandinavian Ice Sheet. Quaternary Science Reviews 34, please add page numbers.

Bosch, J.H.A. 1990. Toelichtingen bij de Geologische Kaart van Nederland 1:50.000, blad Assen West (12W) en blad Assen Oost (12O). Rijks Geologische Dienst, Haarlem (1990) pp. 188

Bøe, A.-G., Murray, A., Dahl, S.O. 2007. Resetting of sediments mobilised by the LGM icesheet in southern Norway. Quaternary Geochronology 2, 222-228.

Böse, M. 1990. Reconstruction of Ice Flow Directions South of the Baltic Sea during the Saalian and Weichselian Glaciations. Boreas 19, 217-226.

Boston, C.M., Evans, D.J.A., Ó. Cofaigh, C. 2010. Styles of till deposition at the margin of the Last Glacial Maximum North Sea lobe of the British-Irish Ice Sheet: an assessment based on 
geochemical properties of glacigenic deposits in eastern England. Quaternary Science Reviews 29, 3184-3211.

Bøtter-Jensen, L., McKeever, S.W.S., Wintle, A.G. 2003. Optically Stimulated Luminescence Dosimetry. Elsevier, Amsterdam, 355p.

Boulton, G.S. 1996. Theory of glacial erosion, transport and deposition as a consequence of subglacial sediment deformation. Journal of Glaciology 42, 43-62.

Boulton, G.S., Clark, C.D., 1990. A highly mobile Laurentide ice sheet revealed by satellite images of glacial lineations. Nature 346, 813-817.

Boulton, G.S., Dongelmans, P., Punkari, M., Broadgate, M. 2001. Palaeoglaciology of an ice sheet through a glacial cycle: the European ice sheet through the Weichselian. Quaternary Science Reviews 20, 591-625

Boulton, G.S., Hagdorn, M., Maillot, P.B., Zatsepin, S. 2009. Drainage beneath ice sheets: groundwater-channel coupling, and the origin of esker systems from former ice sheets. Quaternary Science Reviews 28, 621-638.

Boulton, G.S., Jones, A.S. 1979. Stability of temperate ice caps and ice sheets resting on beds of deformable sediment. Journal of Glaciology 24, 29-43.

Boulton, G.S., Smith, G.D., Jones, A.S., Newsome, J. 1985. Glacial geology and glaciology of the last mid-latitude ice sheets. Journal of the Geological Society, London 142, 447-474.

Bowen, D.Q. (Ed.) 1999a. A Revised Correlation of Quaternary Deposits in the British Isles. Geological Society of London Special Report No. 23.

Bowen, D.Q., Rose, J., McCabe, M.A., Sutherland, D.G. 1986. Correlation of Quaternary glaciations in England, Ireland, Scotland and Wales. Quaternary Science Reviews 5, 299340.

Bowen, D.Q., Phillips, F.M., McCabe, A.M., Knutz, P.C., Sykes, G.A. 2002. New data for the Last Glacial Maximum in Great Britain and Ireland. Quaternary Science Reviews 21, 89-101.

Bradwell, T., Fabel, D., Stoker, M., Mathers, H., McHargue, L., Howe, J. 2008a. Ice caps existed throughout the Lateglacial Interstadial in northern Scotland. Journal of Quaternary Science 23, 401-407.

Bradwell, T., Stoker, M.S., Golledge, N.R., Wilson, C.K., Merritt, J.W., Long, D., Everest, J.D., Hestvik, O.B., Stevenson, A.G., Hubbard, A.L., Finlayson, A.G., Mathers, H.E. 2008c. The northern sector of the last British Ice Sheet: maximum extent and demise. Earth Science Reviews 88, 207-226.

Bradwell, T., Stoker, M., Krabbendam, M. 2008b. Megagrooves and streamlined bedrock in NW Scotland: the role of ice streams in landscape evolution. Geomorphology 97, 135-156.

Bradwell, T., Stoker, M., Larter, R. 2007. Geomorphological signature and flow dynamics of The Minch palaeo-ice stream, northwest Scotland. Journal of Quaternary Science 22, 609617.

Bridgland, D. R., Maddy, D., Bates, M. 2004. River terrace sequences: templates for Quaternary geochronology and marine-terrestrial correlation. Journal of Quaternary Science 19, 203-218.

Buckland, W. 1823. Reliquiae Diluvianae; or, observations on the organic remains contained in caves, fissures, and diluvial gravel, and on other geological phenomena, attesting to the action of an universal deluge. Murray, London. 
Busschers, F.S., Kasse, C., van Balen, R.T., Vandenberghe, J., Cohen, K.M., Weerts, H.J.T., Wallinga, J., Johns, C., Cleveringa, P., Bunnik, F.P.M. 2008. Late Pleistocene evolution of the Rhine-Meuse system in the southern North Sea basin: imprints of climate change, sealevel oscillation and glacio-isostacy. Quaternary Science Reviews 26, 3216-3248.

Cameron, T.D.J., Stoker, M.S., Long, D. 1987. The history of Quaternary sedimentation in the UK sector of the North Sea Basin. Journal of the Geological Society 144, 43-58.

Cameron, T.J.D., Crosby, A., Balson, P.S., Jeffery, D.H., Lott, G.K., Bulat, J., Harrison, D.J. 1992. The Geology of the southern North Sea., United Kingdom Offshore Regional Report, British Geological Survey.

Carr, S.J. 2004. The North Sea basin, In: Ehlers, J., Gibbard, P.L. (Eds.), Developments in Quaternary Science. Elsevier, pp. 261-270.

Carr, S.J., Holmes, R., van der Meer, J.J.M., Rose, J. 2006. The Last Glacial Maximum in the North Sea Basin: micromorphological evidence of extensive glaciation. Journal of Quaternary Science 21, 131-153.

Caspers, G., Jordan, H., Merkt, J., Meyer, K.-D., Müller, H., Streif, H. 1995. Niedersachsen. In: Benda, L. (ed). Das Quartär Deutschlands, 23-58.

Catt, J.A., Penny, L.F. 1966. The Pleistocene deposits of Holderness, East Yorkshire. Proceedings of the Yorkshire Geological Society 35, 375-420.

Cepek, A. G. 1962. Zur Grundmoränenstratigraphie in Brandenburg. Berichte der geologischen Gesellschaft der DDR 6, 2, 275-404.

Cepek, A. G. 1965. Die Stratigraphie der pleistozänen Ablagerungen im Norddeutschen Tiefland. In: Die Weichsel-Eiszeit im Gebiet der DDR, 45-65; Berlin.

Charlesworth, J.K., 1955. Lateglacial history of the Highlands and islands of Scotland. Transactions of the Royal Society of Edinburgh, 62, 769-928.

Chow, N., Morad, S., Al-Aasam, I. 1996. Origin of authigenic carbonate in Eocene to Quaternary sediments from the Arctic Ocean and Norwegian Greenland Sea. In: Thiede, J., Myhre, A.M., Firth, J.V., Johnson, G.L., Ruddiman, W.F. (Eds.), Proceedings of the Ocean Drilling Program, Scientific Results, 151. Ocean Drilling Program, College Station, Texas, 415-434.

Clark, C.D., Evans, D.J., Khatwa, A., Bradwell, T., Jordan, C.J., Marsh, S.H., Mitchell, W.A., Bateman, M.D. 2004. Map and GIS database of glacial landforms and features related to the last British Ice Sheet. Boreas 33, 359-375.

Clark, C.D., Hughes, A.L.C., Greenwood, S.L., Jordan, C., Sejrup, H.-P. 2012. Pattern and timing of retreat of the last British-Irish Ice Sheet. Quaternary Science Reviews 34, please add page numbers.

Clark, P.U., Archer, D., Pollard, D., Blum, J.D., Rial, J.A., Brovkin, V., Mix, A.C., Pisias, N.G., Roy, M. 2006. The middle Pleistocene transition: characteristics, mechanisms, and implications for long-term changes in atmospheric pCO2. Quaternary Science Reviews 25, 3150-3184

Cohen K.M. and Gibbard, P. 2011. Global chronostratigraphical correlation table for the last 2.7 million years. Subcommission on Quaternary Stratigraphy (International Commission on Stratigraphy), Cambridge, England.

Dahlgren, K.I.T., Vorren, T.O., Stoker, M.S., Nielsen, T., Nygård, A., Sejrup, H.P. 2005. Late Cenozoic prograding wedges on the NW European continental margin: their formation and relationship to tectonics and climate. Marine and Petroleum Geology 22, 1089-1110. 
Davies, B.J., Roberts, D.H., Bridgland, D.R., Cofaigh, C.Ó., Riding, J.B., 2011. Provenance and depositional environments of Quaternary sediments from the western North Sea Basin. Journal of Quaternary Science 26, 59-75.

Davies, B.J., Roberts, D.H., Bridgland, D.R., O' Cofaigh. C., Riding, J.B., Demarchi, B., Penkman, K.E.H., Pawley, S.M. 2012. Timing and depositional environments of a Middle Pleistocene glaciation of northeast England: new evidence from Warren House Gill, County Durham. Quaternary Science Reviews 34, please add page numbers.

Dreimanis, A. 1939. Eine neue Methode der quantitativen Geschiebeforschung. Zeitschrift für Geschiebeforschung 15, 17-36.

Duller, G.A.T. 2006. Single grain optical dating of glacigenic deposits. Quaternary Geochronology 1, 296-304.

Duller, G.A.T., Wintle, A.G., Hall, A.M. 1995. Luminescence dating and its application to key Pre-Late Devensian sites in Scotland. Quaternary Science Reviews 14, 495-519.

Ehlers, J. 1990. Reconstructing the dynamics of the North-west European Pleistocene ice sheets. Quaternary Science Reviews 9, 71-83.

Ehlers, J. 2011. Das Eiszeitalter, 363 p., Spektrum, Heidelberg.

Ehlers, J., Eissmann, L., Lippstreu, L., Stephan, H.-J., Wansa, S. 2004. Pleistocene glaciations of North Germany. In: Ehlers, J., Gibbard, P.L. (Eds.), Developments in Quaternary Science. Elsevier, 135-146.

Ehlers, J., Gibbard, P.L. 2007. The extent and chronology of Cenozoic Global Glaciation. Quaternary International 164-165, 6-20.

Ehlers, J., Grube, A., Stephan, H.-J., Wansa, S. 2011. Pleistocene Glaciations of North Germany - New Results. In: Ehlers, J., Gibbard, P. L., Hughes, P. D. (Eds.): Quaternary Glaciations - Extent and Chronology. A closer look. Developments in Quaternary Science, 15, 149-162.

Ehlers, J., Meyer, K.-D., Stephan, H.-J. 1984. The pre-Weichselian glaciations of North-West Europe. Quaternary Science Reviews 3, 1-40.

Ehlers, J., Stephan, H.-J. 1983. Till fabric and ice movement. In: The Glacial Deposits in North-West Europe, 267-274, Rotterdam.

Eissmann, L. 1995. The pre-Elsterian Quaternary deposits of central Germany. In: Ehlers, J., Kozarski, S. \& Gibbard, P. L. (eds) Glacial Deposits in North-East Europe. Balkema, Rotterdam, 423-437.

Eissmann, L. 1997. Das quartäre Eiszeitalter in Sachsen und Nordostthüringen. Landschaftswandel am Südrand des skandinavischen Vereisungsgebietes. Altenburger naturwissenschaftlichen Forschungen 8, 1-98.

Eissmann, L. 2002. Quaternary geology of eastern Germany (Saxony, Saxon-Anhalt, South Brandenburg, Thüringia), type area of the Elsterian and Saalian Stages in Europe. Quaternary Science Reviews 21, 1275-1346.

Ekman, S.R. 1998. Middle Pleistocene pollen biostratigraphy in the central North Sea. Quaternary Science Reviews 17, 931-944.

Ekman, S.R. 1999. Early Pleistocene pollen biostratigraphy in the central North Sea. Review of Palaeobotany and Palynology 105, 171-182. 
Evans, D.J.A., Clark, C.D., Mitchell, W.A. 2005. The last British ice sheet: a review of the evidence utilised in the compilation of the glacial map of Britain. Earth-Science Reviews 70 , 253-312.

Evans, D.J.A., Phillips, E.R., Hiemstra, J.F., Auton, C.A. 2006. Subglacial till: Formation, sedimentary characteristics and classification. Earth-Science Reviews 78, 115-176.

Evans, D.J.A. Twigg, D.R., 2002. The active temperate glacial landsystem: a model based on Breidamerkurjökull and Fjallsjökull, Iceland. Quaternary Science Reviews 21, 2143-2177.

Everest, J., Bradwell, T. 2003. Buried glacier ice in southern Iceland and its wider significance. Geomorphology 52, 347-358.

Flesche Kleiven, H., Jansen, E., Fronval, T., Smith, T.M. 2002. Intensification of Northern Hemisphere glaciations in the circum Atlantic region (3.5-2.4 Ma) - ice-rafted detritus evidence. Palaeogeography, Palaeoclimatology, Palaeoecology 184, 213-223.

Forman, S.L. 1999. Infrared and Red Stimulated Luminescence Dating of Late Quaternary Near-shore Sediments from Spitsbergen, Svalbard. Artic, Antarctic, and Alpine Research 31, 34-49.

Fronval, T., Jansen, E. 1996. Late Neogene paleoclimates and paleoceanography in the Iceland-Norwegian Sea: evidence from the Iceland and Vøring Plateaus. Proceedings of the Ocean Drilling Program, Scientific Results 151, 455-468.

Fuchs, M., Owen, L.A. 2008. Luminescence dating of glacial and associated sediments: review, recommendations and future directions. Boreas 37, 636-659.

Gaigalas, A. 1975. Lithogenetic, lithostratigraphic and paleogeographic significance of the petrographic composition of Lithuanian Pleistocene moraines. In: Till - its Genesis and Diagenesis. - Uniwersytet Im. Adama Mickiewicza w Poznaniu, Seria Geografia nr. 12, 213217, Poznań.

Gaigalas, A. and Gudelis, V. 1965. Erratische Geschiebe stadialer Bildungen der letzten Vereisung im südlichen Baltikum und die Dynamik des Inlandeises (Translation by O. S. Döll). - From: Baltica 2, 213-227.

Gałązka, D. 2004. Investigation of Scandinavian erratics from tills in the interlobate zone, llawa region, northern Poland. International Field Symposium on Quaternary Geology and modern Terrestrial Processes, Riga, 15-16.

Gemmell, A.M.D., Murray, A.S., Connell, E.R. 2007. Devensian glacial events in Buchan (NE Scotland): A progress report on new OSL dates and their implications. Quaternary Geochronology 2, 237-242.

Gibbard, P.L. 1988. The history of the great northwest European rivers during the past three million years. Philosophical Transactions of the Royal Society of London B318, 559-602.

Gibbard, P. L., Pasanen, A. H., West, R. G., Lunkka, J. P., Boreham, S., Cohen, K. M. and Rolfe, C. 2009. Late Middle Pleistocene glaciation in East Anglia, England. Boreas, 38, 504528.

Gibbard, P.L., West, R.G., Andrew, R., Pettit, M., 1992. The margin of a Middle Pleistocene ice advance at Tottenhill, Norfolk, England. Geological Magazine 129, 59-76.

Godfrey-Smith, D.I., Huntley, D.J., Chen, W.H., 1988. Optical dating studies of quartz and feldspar sediment extracts. Quaternary Science Reviews 7, 379-385. 
Górska-Zabielska, M. 2008. Fennoskandzkie obszary alimentacyjne osadów akumulacji glacjalnej e glacjofluwialnej lobu Odry. Uniwersytet Im. Adama Mickiewicza W Poznaniu, Seria Geografia nr. 78, 330 p., Poznań.

Gozhik, P., Lindner, L., Marks, L. in press. Late Early and early Middle Pleistocene limits of Scandinavian glaciations in Poland and Ukraine. Quaternary International, doi:10.1016/j.quaint.2010.07.027

Graham, A.G.C. 2007. Reconstructing Pleistocene Glacial Environments in the Central North Sea using 3D seismic and borehole data. Unpublished PhD thesis, Imperial College London, p. 410.

Graham, A.G.C., Lonergan, L., Stoker, M.S. 2007. Evidence for Late Pleistocene ice stream activity in the Witch Ground Basin, central North Sea, from 3D seismic reflection data. Quaternary Science Reviews 26, 627-643.

Graham, A.G.C., Lonergan, L., Stoker, M.S., 2009. Seafloor glacial features reveal the extent and decay of the last British Ice Sheet, east of Scotland. Journal of Quaternary Science 24, 117-138.

Graham, A.G.C., Stoker, M.S., Lonergan, L., Bradwell, T., Stewart, M.A., 2011. The Pleistocene Glaciations of the North Sea Basin, In: Ehlers, J., Gibbard, P.L., Hughes, P.D. (Eds.), Quaternary Glaciations - Extent and Chronology, a closer look. Development in Quaternary Science, Vol 15. Elsevier, Amsterdam, pp. 261-278.

Gripp, K. 1924. Über die äußerste Grenze der letzten Vereisung in Nordwest-Deutschland. Mitteilungen der Geographischen Gesellschaft in Hamburg 36, 159-245.

Grousset, F., Pujol, C., Labeyrie, L., Auffret, G., Boelaert, A. 2000. Were the North Atlantic Heinrich events triggered by the behaviour of the European ice sheets? Geology 28, 123-126.

Grube, F. 1979. Übertiefte Rinnen im Hamburger Raum. Eiszeitalter und Gegenwart 29, 157172.

Grün, R., Schwarcz, H.P. 2000. Revised open system U-series/ESR age calculations for teeth from Stratum $C$ at the Hoxnian Interglacial type locality, England. Quaternary Science Reviews 19, 1151-1154.

Hamblin, R.J.O., Moorlock, B.S.P., Rose, J., 2000. A new glacial stratigraphy for Eastern England. Quaternary Newsletter 92, 35-43.

Hamblin, R.J.O., Moorlock, B.S.P., Rose, J., Lee, J.R., Riding, J.B., Booth, S.J., Pawley, S.M., 2005. Revised pre-Devensian glacial stratigraphy in Norfolk, England, based on mapping and till provenance. Netherlands Journal of Geosciences 84, 77-85.

Helmke, J.P., Bauch, H.A., Erlenkeuser, H. 2003. Development of glacial and interglacial conditions in the Nordic seas between 1.5 and $0.35 \mathrm{Ma}$. Quaternary Science Reviews 22, 1717-1728.

Henrich, R., Baumann, K.H., 1994. Evolution of the Norwegian Current and the Scandinavian Ice Sheets during the past 2.6 m.y.: evidence from ODP Leg 104 biogenic carbonate and terrigenous records. Palaeogeography, Palaeoclimatology, Palaeoecology 108, 75-94.

Hentschke, U. and Stephan, H.-J. 1989. Schwermineralanalyse von Geschiebemergeln, ein Hilfsmittel für die Moränenstratigraphie? Diskussion anhand von Zählungen aus SchleswigHolstein. E \& G - Quaternary Science Journal 39, 19-28.

Hesemann, J. 1932. Die bisherigen Geschiebezählungen aus dem norddeutschen Diluvium im Diagramm. Zeitschrift für Geschiebeforschung 8, 3, 164-187. 
Hey, R.W., Brenchley, P.J. 1977. Volcanic pebbles from Pleistocene gravels in Norfolk and Essex. Geological Magazine 114, 219-225.

Hölemann, J.A., Henrich, R. 1994. Allochthonous versus autochthonous organic matter in Cenozoic sediments of the Norwegian Sea: Evidence for the onset of glaciations in the northern hemisphere. Marine Geology 121, 87-103.

Hinsch, W. 1979. Rinnen an der Basis des glaziären Pleistozäns in Schlewig-Holstein. Eiszeitalter und Gegenwart 29, 173-178.

Holmes, R. 2003. Offshore Stratigraphical Record. In: Merritt, J., Auton, C.A., Connell, E.R., Hall, A.M., Peacock, J.D. (Eds.), Cainozoic geology and landscape evolution of north-east Scotland. Memoir of the British Geological Survey, Sheets 66E, 67, 76E, 77, 86E, 87W, 95, 96W, 96E and 97 (Scotland). HMSO, London, pp. 57-64.

Houmark-Nielsen, M. 1983. The compositional features of Danish glacial deposits. In: Ehlers, J. (ed.) The Glacial Deposits in North-West Europe, 211-217, Rotterdam.

Houmark-Nielsen, M. 1987. Pleistocene stratigraphy and glacial history of the central part of Denmark. Bulletin of the geological Society of Denmark 36, 189.

Houmark-Nielsen, M. 2004. The Pleistocene of Denmark: a review of stratigraphy and glacial history, In: Ehlers, J., Gibbard, P.L. (Eds.), Quaternary Glaciations - Extent and Chronology. Part I, Europe. Elsevier, 35-46.

Houmark-Nielsen, M. 2007. Extent and age of Middle and Late Pleistocene glaciations and periglacial episodes in southern Jylland, Denmark. Bulletin of the Geological Society of Denmark 55, 9-35.

Houmark-Nielsen, M. 2008. Testing OSL failures against a regional Weichselian glaciation chronology from Southern Scandinavia. Boreas 37, 660-677.

Houmark-Nielsen, M. 2010. Extent, age and dynamics of Marine Isotope Stage 3 glaciations in the southwestern Baltic Basin. Boreas 39, 343-359.

Houmark-Nielsen, M., Kjær, K. 2003. Southwest Scandinavia, 40-15 kyr BP: palaeogeography and environmental change. Journal of Quaternary Science 18, 769-786.

Hubbard, A. Bradwell, T., Golledge, N., Hall, A., Patton, H., Sugden, D., Cooper, R., Stoker, M. 2009. Dynamic cycles, ice streams and their impact on the extent, chronology and deglaciation of the British-Irish ice sheet. Quaternary Science Reviews, 758-776.

Huuse, M., Lykke-Andersen, H. 2000. Overdeepened Quaternary valleys in the eastern Danish North Sea: morphology and origin. Quaternary Science Reviews 19, 1233-1253.

Hughes, P.D. 2010. Geomorphology and Quaternary stratigraphy: The roles of morpho-, litho-, and allostratigraphy. Geomorphology 123, 189-199.

Huot, S., Lamothe, M. 2003. Variability of infrared stimulated luminescence properties from fractured feldspar grains. Radiation Measurements 37, 499-503.

Huntley, D.J., Godfrey-Smith, D.I., Thewalt, M.L.W. 1985. Optical dating of sediments. Nature 313, 105-107.

Hütt, G., Jaeck, I., Tconka, Y. 1988. Optical dating: K-feldspars optical response stimulation spectra. Quaternary Science Reviews 7, 381-386.

Janocko, J., Landvik, J.Y., Larsen, E., Sejrup, H.P. 1997. Stratigraphy and sedimentology of Middle and Upper Pleistocene sediments in the new Grødaland borehole at Jæren, SW Norway. Norges Geologiske Tidsskrift 77, 87-100. 
Jansen, E., Fronval, T., Rack, F., Channell, J.E.T. 2000. Pliocene-Pleistocene ice rafting history and cyclicity in the Nordic Seas during the last 3 Myr. Paleoceanography 15, 709-721.

Jansen, E., Sjøholm, J., 1991. Reconstruction of glaciation over the past 6 Myr from icebourne deposits in the Norwegian Sea. Nature 349, 600-603.

Johnsen, T.F., Olsen, L., Murray, A. 2012. OSL ages in central Norway support a MIS 2 interstadial (25-20 ka) and a dynamic Scandinavian ice sheet. Quaternary Science Reviews, 34 , please add page numbers.

Kalm, V. 2012. Ice-flow pattern and extent of the last Scandinavian Ice Sheet southeast of the Baltic Sea. Quaternary Science Reviews, 34, please add page numbers.

Keilhack, K. 1909. Begleitworte zur Karte der Endmoränen und Urstromtäler Norddeutschlands. Jahrbuch der Königlich Preußischen geologischen Landesanstalt und Bergakademie zu Berlin, 30, 507-510.

King, E.L., Haflidason, H., Sejrup, H.P., Lovlie, R. 1998. Glacigenic debris flows on the North Sea Trough Mouth Fan during ice stream maxima. Marine Geology 152, 217-246.

King, E.L., Sejrup, H.P., Haflidason, H., Elverhøi, A., Aarseth, I. 1996. Quaternary seismic stratigraphy of the North Sea Fan: glacially-fed gravity flow aprons, hemipelagic sediments, and large submarine slides. Marine Geology 130, 293-315.

Kjær, K.H., Houmark-Nielsen, M., Richardt, N. 2003. Ice-flow patterns and dispersal of erratics at the southwestern margin of the last Scandinavian Ice Sheet: signature of palaeoice streams. Boreas 32, 130-148.

Kjær, K.H., Lagerlund, E., Adrielsson, L., Thomas, P.J., Murray, A., Sandgren, P. 2006. The first independent chronology for Middle and Late Weichselian sediments from southern Sweden and the Island of Bornholm. GFF 128, 209-220.

Kluiving, S.J., Rappol, M., Van der Wateren, F.M., 1991. Till stratigraphy and ice movements in eastern Overijssel, The Netherlands. Boreas 20, 193-205.

Kluiving, S.J., Aleid Bosch, J.H., Ebbing, J.H.J., Mesdag, C.S., Westerhoff, R.S. 2003. Onshore and offshore seismic and lithostratigraphic analysis of a deeply incised Quaternary buried valley system in the Northern Netherlands. Journal of Applied Geophysics 53, 249271.

Knies, J., Matthiessen, J., Vogt, C., Laberg, J.S., Hjelstuen, B.O., Smelror, M., Larsen, E., Andreassen, K., Eidvin, T., Vorren, T.O. 2009. The Plio-Pleistocene glaciation of the Barents Sea-Svalbard region: a new model based on revised chronostratigraphy. Quaternary Science Reviews 28, 812-829.

Knies, J., Matthiessen, J., Vogt, C., Stein, R. 2002. Evidence of 'Mid-Pliocene ( $\sim 3 \mathrm{Ma})$ global warmth' in the eastern Arctic Ocean and implications for the Svalbard/Barents Sea ice sheet during the late Pliocene and early Pleistocene $(\sim 3-1.7 \mathrm{Ma})$. Boreas 31, 82-93.

Knight, J., Coxon, P., McCabe, A.M., McCarron, S.G. 2004. Pleistocene glaciations in Ireland. Quaternary Glaciations Extent and Chronology - Part I: Europe, 183-191. Developments in Quaternary Sciences Volume 2.

Knutz, P.C., Austin, W.E.N., Jones, E.J.W. 2001. Millennial-scale depositional cycles related to British Ice Sheet variability and North Atlantic palaeocirculation since $45 \mathrm{kyr}$ BP, Barra Fan, UK margin. Paleoceanography 16, 53-64. 
Knutz, P.C., Jones, E.J.W., Austin, W.E.N., van Weering, T.C.E. 2002. Glacimarine slope sedimentation, contourite drifts and bottom current pathways on the Barra Fan, UK North Atlantic margin. Marine Geology 188, 129-146.

Korn, J. 1927. Die wichtigsten Leitgeschiebe der nordischen kristallinen Gesteine im norddetschen Flachland. Preußische Geologische Landes-Anstalt; Berlin.

Kozarski, S. 1995. Deglacjacja pólnocno-zachodniej Polski: womki i trasformacja geosystema ( 20ka - 10 ka) - IG; PZPAN, Documentacja Geograficzna 1, 82.

Krbetschek, M., Degring, D. and Alexowsky, W. 2008. Infrarot-Radiofluoreszenz-Alter (IR-RF) unter-saalezeitlicher Sedimente Mittel- und Ostdeutschlands. Zeitschrift der Deutschen Gesellschaft für Geowissenschaften 159/1, 133-140.

Krissek, L.A. 1989. Late Cenozoic records of ice-rafting at ODP sites 642, 643 and 644, Norwegian Sea: onset, chronology, and characteristics of glacial/interglacial fluctuations. In: Eldholm, O., Thiede, J., Taylor, E. (Eds.), Proceedings of the Ocean Drilling Project. Scientific Results, 104, 61-69.

Krzyszkowski, D. 1995. An outline of the Pleistocene stratigraphy of the Kleszczów Graben, Bełchatów outcrop, central Poland. Quaternary Science Reviews 14, 61-83.

Kuhlmann, G., Wong, T.E. 2008. Pliocene paleoenvironment evolution as interpreted from 3D-seismic data in the southern North Sea, Dutch offshore sector. Marine and Petroleum Geology 25, 173-189.

Kuster, H., Meyer, K.-D. 1979. Glaziäre Rinnen im mittleren und nördlichen Niedersachsen. Eiszeitalter und Gegenwart 29, 135-156.

Laban, C. 1995. The Pleistocene glaciations in the Dutch sector of the North Sea. A synthesis of sedimentary and seismic data. PhD Thesis, University of Amsterdam.

Laban, C., van der Meer, J.J.M. 2004. Pleistocene glaciation in The Netherlands, In: Ehlers, J., Gibbard, P.L. (Eds.), Developments in Quaternary Science. Elsevier, pp. 251-260.

Laban, C., van der Meer, J.J.M., 2011. Pleistocene Glaciation in The Netherlands, In: Ehlers, J., Gibbard, P.L., Hughes, P.D. (Eds.), Quaternary Glaciations - Extent and Chronology a closer look, Developments in Quaternary Science Vol. 15. Elsevier, Amsterdam.

Lang, J., Winsemann, J., Steinmetz, D., Polom, U., Pollok, L., Böhner, U., Serangeli, J., Brandes, Ch., Hampel, A., Winghart, S., 2012. The Pleistocene of Schöningen, Germany: a complex tunnel valley fill revealed from 3D subsurface modelling and shear wave seismics. Quaternary Science Reviews, 39, 86-105.

Larkin, N.R., Lee, J.R., Connell, E.R. 2011. Possible ice-rafted erratics in late Early to early Middle Pleistocene shallow marine and coastal deposits in northeast Norfolk, UK. Proceedings of the Geologists' Association 122, 445-454.

Larsen, B., Andersen, L.T. 2005. Late Quaternary stratigraphy and morphogenesis in the Danish eastern North Sea and its relation to onshore geology. Netherlands Journal of Geosciences 84, 113-128.

Larsen, E., Kjær, K.H., Demidov, I., Funder, S., Grøsfjeld, K., Houmark-Nielsen, M., Jensen, M., Linge, H., Lyså, A. 2006. Late Pleistocene glacial and lake history of northwestern Russia. Boreas 35, 394-424.

Larsen, E., Lyså, A., Demidov, I., Funder, S., Houmark-Nielsen, M., Kjær, K.H., Murray, A.S. 1999. Age and extent of the Scandinavian ice sheet in northwest Russia. Boreas 28, 115132. 
Larson, P., Mooers, H. 2005. Generation of a heavy-mineral glacial indicator dispersal train from a diabase sill, Nipigon region, northwestern Ontario. Canadian Journal of Earth Sciences 42, 1601-1613.

Lee, J.R., Busschers, F.S., Sejrup. H.-P. 2012. Pre-Weichselian Quaternary glaciations of the British Isles, The Netherlands, Norway and adjacent marine areas south of $68 \mathrm{~N}$ : implications for long-term ice sheet development in northern Europe. Quaternary Science Reviews, 34, please add page numbers.

Lee, J.R., Pawley, S.M., Rose, J., Moorlock, B.S.P., Hamblin, R.J.O., Candy, I., Barendregt, R.W., Booth, S.J., Harrison, A.M. 2008. Pre-Devensian lithostratigraphy of shallow marine, fluvial and glacial deposits in northern East Anglia, In: Candy, I., Lee, J.R., Harrison, A.M. (Eds.), Quaternary of northern East Anglia - Field Guide. Quaternary Research Association, Edinburgh, 42-59.

Lee, J.R., Rose, J., Riding, J.B., Moorlock, B.S.P., Hamblin, R.J.O., 2002. Testing the case for a Middle Pleistocene Scandinavian glaciation in Eastern England: evidence for a Scottish ice source for tills within the Corton Formation of East Anglia, UK. Boreas 31, 345-355.

Lee, J.R., Rose, J., Hamblin, R.J., Moorlock, B.S. 2004. Dating the earliest lowland glaciation of eastern England: a pre-MIS 12 early Middle Pleistocene Happisburgh glaciation. Quaternary Science Reviews 23, 1551-1566.

Lekens, W.A.H., Sejrup, H.P., Haflidason, H., Petersen G.Ø., Hjelstuen, B., Knorr, G. 2005. Laminated sediments preceding Heinrich event 1 in the Northern North Sea and Southern Norwegian Sea: Origin, processes and regional linkage Marine Geology 216, 27-50

Lian, O.B., Roberts, R.G. 2006. Dating the Quaternary: progress in luminescence dating of sediments. Quaternary Science Reviews 25, 2449-2468.

Liedtke, H. 1975. Die Nordischen Vereisungen in Mitteleuropa. Forschungen zur deutschen Landeskunde 204, Bonn - Bad Godesberg; 2. Auflage 1981.

Lippstreu, L., 1995: with contribution of Fritz Brose and Joachim Marcinek: Brandenburg, 116147. In: Benda, L.: Das Quartär Deutschlands. Berlin, Stuttgart.

Litt, T., Behre, K.-E., Meyer, K.-D., Stephan, H.-J. and Wansa, S. 2007. Stratigraphische Begriffe für das Quartär des norddeutschen Vereisungsgebietes. E \& G - Quaternary Science Journal Vol. 56 No 1-2, 7-65.

Litt, T., Schmincke, H.-U., Frechen, M., Schlüchter, C., 2008. Quaternary. In: McCann, T. (Ed.), The Geology of Central Europe. Geological Society of London, 1287-1340.

Livingstone, S.J., Evans, D.J.A., Ó Cofaigh, C. 2010a. Re-advance of Scottish ice into the Solway Lowlands (Cumbria, UK) during the Main Late Devensian deglaciation. Quaternary Science Reviews, 29, 2544-2570.

Livingstone, S.J., Evans, D.J.A., Ó Cofaigh, C., Hopkins, J. 2010b. The Brampton kame belt and Pennine escarpment meltwater channel system (Cumbria, UK): Morphology, sedimentology and formation, 121, 423-443.

Long, D., Laban, C., Streif, H., Cameron, T.D.J., Schuttenhelm, R.T.E., Paepe, R. 1988. The Sedimentary Record of Climatic Variation in the Southern North Sea. Philosophical Transactions of the Royal Society of London. B, Biological Sciences 318, 523-537.

Lunkka, J.P., Saarnisto, M., Gey, V., Demidov, I., Kiselova, V. 2001. Extent and age of the Last Glacial Maximum in the southeastern sector of the Scandinavian Ice Sheet. Global and Planetary Change 31, 407-425. 
Lüthgens, C., Böse, M. 2011. Chronology of Weichselian main ice marginal positions in north-eastern Germany. E \& G Quaternary Science Journal 60, 236-247.

Lüthgens, C., Böse, M. 2012. From morphostratigraphy to geochronology - on the dating of ice marginal positions. Quaternary Science Reviews, 34, please add page numbers.

Lüthgens, C., Böse, M., Krbetschek, M. 2010. On the age of the young morainic morphology in the area ascribed to the maximum extent of the Weichselian glaciation in north-eastern Germany. Quaternary International 222, 72-79.

Lüttig, G. 1958. Methodische Fragen der Geschiebeforschung. Geologisches Jahrbuch 75, 361-418.

Mangerud, J., Astakhov, V.I., Murray, A., Svendsen, J.I. 2001. The chronology of a large icedammed lake and the Barents-Kara Ice Sheet advances, Northern Russia. Global and Planetary Change 31, 321-336.

Marks, L. 2002. Last Glacial Maximum in Poland. Quaternary Science Reviews 21, 103-110.

Marks, L. 2011: Quaternary Glaciations in Poland. In: Ehlers, J., Gibbard, P. L., Hughes, P. D. (Eds.): Quaternary Glaciations - Extent and Chronology. A closer look. Developments in Quaternary Science, 15, 299-303; Elsevier.

Marks, L. 2012. Timing of the Late Vistulian (Weichselian) glacial phases in Poland. Quaternary Science Reviews, 34, please add page numbers.

Marks, L., Piotrowski, J. A., Stephan, H.-J., Fedorowicz, S., Butrym, J. (1995). Thermoluminescence indications of the Middle Weichselian (Vistulian) Glaciation in northwest Germany. Meyniana, 47: 69-82; Kiel.

Martin, J. 1898. DiluvialstudienVII. Über die Stromrichtungen des nordeuropäischen Inlandeises. - Abhandlungen des naturwissenschaftlichen Vereins Bremen (cited in Milthers 1934).

Martin, J. 1906. Das Studium der eratischen Gesteine im Dienste der Glacialforschung. Schriften des Oldenburger Vereins für Altertumskunde und Landesgeschichte (cited in Milthers 1934).

McMillan, A.A. 2005. A provisional Quaternary and Neogene lithostratigraphical framework for Great Britain. Netherlands Journal of Geosciences 84, 87-107.

Meijer, T., Cleveringa, P., 2009. Aminostratigraphy of Middle and Late Pleistocene deposits in The Netherlands and the southern part of the North Sea Basin. Global and Planetary Change 68, 326-345.

Meyer, K.-D. 1983. Indicator pebble and stone count methods. In: Ehlers, J. (ed.) The Glacial Deposits in North-West Europe, 275-288, Rotterdam.

Meyer, K.-D. 2005. Zur Stratigraphie des Saale-Glazials in Niedersachsen und zu Korrelationsversuchen mit Nachbargebieten. E \& G - Quaternary Science Journal 55, 1, 2542.

Mitchell, G.F., Penny, L.F., Shotton, F.W. and West, R.G. 1973. A correlation of Quaternary deposits in the British Isles. Geological Society of London, Special Report, 4, $99 \mathrm{pp}$.

Mitchell, W.A., Bridgland, D.R., Innes, J.B. 2010. Late Quaternary evolution of the TeesSwale interfluve east of the Pennines: the role of glaciation in the development of river systems in northern England, 121, 410-422. 
Milthers, V., 1909. Scandinavian Indicator Boulders in the Quaternary Deposits. - Danmarks Geologiske Undersøgelse, II Raekke, 23.

Molodkov, A.N., Bolikhovskaya, N.S., 2006. Long-term palaeoenvironmental changes recorded in palynologically studied loess-palaeosol and ESR-dated marine deposits of Northern Eurasia: Implications for sea-land correlation. Quaternary International 152-153, 3747.

Mudelsee, M., Raymo, M.E. 2005. Slow dynamics of the northern hemisphere glaciation. Paleoceanography 20, PA4200.

Murray, A.S., Wintle, A.G. 2000. Luminescence dating of Quartz using an improved single aliquot regenerative dose protocol. Radiation Measurements 32, 57-73.

Murray, A.S., Wintle, A.G. 2003. The single aliquot regenerative dose protocol: potential for improvements in reliability. Radiation Measurements 37, 377-381.

Murray, T. 1997. Assessing the paradigm shift: deformable glacier beds. Quaternary Science Reviews 16, 995-1016.

Nunberg, J. 1971. Próba zastosowania metod statystycznych do badań zespotu glazów fennoskandyjskich występujących w utworach, glacjalnych północno-wschodniej polski. (Summary: An application of statistical methods to the investigation of fennoscandian erratic boulder associations from teh glacial deposits of the north-eastern Poland). - Studia geologica Polonica XXXVII; Warszawa.

Nygård, A., Sejrup, H.P., Haflidason, H., Bryn, P. 2005. The glacial North Sea Fan, southern Norwegian Margin: architecture and evolution from the upper continental slope to the deepsea basin. Marine and Petroleum Geology 22, 71-84.

Oele, E. and Schuttenhelm, R.T.E. 1979. Development of the North Sea after the Saalian glaciation. In: Quaternary History of the North Sea, pp. 191-216. Acta Universitatis Uppsaliensis, Uppsala.

Olsen, L., van der Borg, K., Bergstrøm, B., Sveian, H., Lauritzen, S.-E., Hansen, G. 2001. AMS radiocarbon dating of glacigenic sediments with low organic carbon content-an important tool for reconstructing the history of glacial variations in Norway. Norges Geologiske Tidsskrift 81, 59-92.

O' Cofaigh, C., Dunlop, P., Benetti, S. 2012a. Marine geophysical evidence for Late Pleistocene ice sheet extent and recession off northwest Ireland. Quaternary Science Reviews, 34, please add page numbers.

Ó Cofaigh, C., Evans, D.J.A., 2007. Radiocarbon constraints on the age of the maximum advance of the British-Irish Ice Sheet in the Celtic Sea. Quaternary Science Reviews 26, 1197-1203.

Ó Cofaigh, C., Taylor, J., Dowdeswell, J.A., Pudsey, C.J. 2003. Palaeo-ice streams, trough mouth fans and high-latitude continental slope sedimentation. Boreas 32, 37-55.

Ó Cofaigh, C., Telfer, M.W., Bailey. R.M., Evans, D.J.A. 2012b. Late Pleistocene chronostratigraphy and ice sheet limits, southern Ireland. Quaternary Science Reviews, 34, please add page numbers.

Overeem, I., Weltje, G.J., Bishop-Kay, C., Kroonenberg, S.B. 2002. The Late Cenozoic Eridanos delta system in the southern North Sea Basin: a climate signal in sediment supply? Basin Research 13, 293-312. 
Pawley, S.M., Bailey, R.M., Rose, J., Moorlock, B.S.P., Hamblin, R.J.O., Booth, S.J., Lee, J.R. 2008. Age limits on Middle Pleistocene glacial sediments from OSL dating, north Norfolk, UK. Quaternary Science Reviews 27, 1363-1377.

Pawley, S.M., Toms, P., Armitage, S.J. Rose, J. 2010. Quartz luminescence dating of Anglian Stage (MIS 12) fluvial sediments: Comparison of SAR age estimates to the terrace chronology of the Middle Thames valley, UK. Quaternary Geochronology 5, 569-582

Peck, V.L., Hall, I.R., Zahn, R., Grousset, F., Hemming, S.R., Scourse, J.D. 2007. The relationship of Heinrich events and their European precursors over the past 60 ka BP: a multiproxy ice-rafted debris provenance study in the North East Atlantic. Quaternary Science Reviews 26, 862-875.

Penck, A. 1879. Die Geschiebeformation Norddeutschlands. Zeitschrift der deutschen geologischen Gesellschaft, 31, 117-203.

Penck, A. 1882. Die Vergletscherung der Deutschen Alpen: ihre Ursachen, Periodische Wiederkehr und ihr Einfluss auf die Bodengestaltung. Barth, Leipzig.

Penkman, K.E.H., Preece, R.C., Bridgland, D.R., Keen, D.H., Meijer, T., Parfitt, S.A. White, T.S., Collins, M.J. 2011. A chronological framework for the British Quaternary based on Bithynia opercula. Nature 476, 446-449

Perrin, R.M.S., Rose, J., Davies, H. 1979. The distribution, variation and origins of preDevensian tills in eastern England. Philosophical Transactions of the Royal Society of London B287, 535-570.

Peters, C., Walden, J., Austin, W.E.N. 2008. Magnetic signature of European margin sediments: provenance of ice-rafted debris and the climatic response of the British Ice Sheet during Marine Isotope Stages 2 and 3. Journal of Geophysical Research - Earth Surface 113, F03007.

Petersen, J.1899/1900. Geschiebestudien - Beiträge zur Kenntnis der Bewegungsrichtungen des diluvialen Inlandeises. Mitteilungen der Geographischen Gesellschaft in Hamburg, Teil 1. Bd.15,1899, 67-130; Teil 2. Bd.16,1900, 139-230.

Petersen, K.-S. 1985. The Late Quaternary History of Denmark. Journal of Danish Archaeology 4, 7-22.

Peuraniemi, V. 1990. Heavy minerals in glacial material. In: Kujansuu, R. and Saarnisto, M., Glacial indicator tracing, 165-185.

Pointon, W.K. 1978. The Pleistocene succession at Corton, Suffolk. Bulletin of the Geological Society of Norfolk, 30, 55-76.

Praeg, D. 2003. Seismic imaging of mid-Pleistocene tunnel-valleys in the North Sea Basin-high resolution from low frequencies. Journal of Applied Geophysics 53, 273-298.

R.C. Preece, R.C., Parfitt, S.A. Bridgland, D.R., Lewis, S.G., Rowe, P.J., Atkinson, T.C., Candy, I., Debenham, N.C., Penkman, K.E.H., Rhodes, E.J., Schwenninger, J.-L., Griffiths, H.I., Whittaker, J.E., Gleed-Owen, C. 2007. Terrestrial environments during MIS 11: evidence from the Palaeolithic site at West Stow, Suffolk, UK. Quaternary Science Reviews 26, 1236 1300

Preece, R.C., Parfitt, S.A., Coope, G.R., Penkman, K.E.H., Ponel, P., Whittaker, J.E. 2009. Biostratigraphic and aminostratigraphic constraints on the age of the Middle Pleistocene glacial succession in north Norfolk, UK. Journal of Quaternary Science 24, 557-580.

Preusser, F. (1999). Lumineszenzdatierung fluviatiler Sedimente - Fallbeispiele aus der Schweiz und Norddeutschland. Kölner Forum für Geologie und Paläontologie, 3, 62pp; Köln. 
Preusser, F., Degering, D., Fuchs, M., Hilgers, A., Kadereit, A., Klasen, N., Krbetschek, M., Richter, D., Spencer, J.Q.G. 2008. Luminescence dating: basics, methods and applications. E \& G- Quaternary Science Journal 57, 1-2, 95-149.

Rappol, M., 1987. Saalian till in The Netherlands: a review. In: Meervan der, J.J.M. (Ed.), Tills and Glaciotectonics. Balkema, Rotterdam, 3-21.

Rappol, M., Haldorsen, S., Jørgensen, P., van der Meer, J.J.M., Stoltenberg, H.M.P. 1989. Composition and origin of petrographically-stratified thick till in the Northern Netherlands and a Saalian glaciation model for the North Sea basin. Mededelingen van de Werkroep voor Tertiaire en Kwartaire Geologie 26, 31-64.

Rawson, P.F., Allen, P.M., Brenchley, P.J., Cope, J.C.W., Gale, A.S., Evans, J.A., Gibbard, P.L., Gregory, F.J., Hailwood, E.A., Hesselbo, S.P., Knox, R.W.O.B., Marshall, J.E.A., Oates, M., Riley, N.J., Smith, A.G., Trewin, N., Zalasiewicz, J.A. 2002. Stratigraphic Procedure. The Geological Society, London.

Riding, J.B., Rose, J., Booth, S.J., 2003. Allochthonous and indigenous palynomorphs from the Devensian of the Warham Borehole, Stiffkey, north Norfolk, England; evidence for the sediment provenance. Proceedings of the Yorkshire Geological Society 54, 223-237.

Rijsdijk, K.F., Passchier, S., Weerts, H.J.T., Laban, C., Van Leeuwan, R.J., Ebbing, J.H.J. 2005. Revised Upper Cenozoic stratigraphy of the Dutch sector of the North Sea Basin: towards an integrated lithostratigraphic, seismostratiographic and allostratigraphic approach. Netherlands Journal of Geosciences 84, 129-146.

Rinterknecht, V., Braucher, R., Böse, M, Bourlès, D. Mercier, J.-L. 2012. Late Quaternary ice sheet extents in northeastern Germany inferred from surface exposure dating. Quaternary Science Reviews, 34, please add page numbers.

Rinterknecht, V.R., Clark, P.U., Raisbeck, G.M., Yiou, F., Bitinas, A., Brook, E.J., Marks, L., Zelcs, V., Lunkka, J.-P., Pavlovskaya, I.E., Piotrowski, J.A., Raukas, A. 2006. The last deglaciation of the southeastern sector of the Scandinavian ice sheet. Science 311, 14491452.

Rørdam, K. 1893. Beskrivelse til kortbladene Helsingør of Hillerød. Danmarks Geologiske Undersøgelse, raekke 1, 1, $110 \mathrm{p}$.

Rose, J. 1974. Small-Scale Spatial Variability of Some Sedimentary Properties of Lodgement Till and Slumped Till. Proceedings of the Geologists' Association 85, 223-237

Rose, J. 1987. The status of the Wolstonian glaciation in the British Quaternary. Quaternary Newsletter, 53, 1-9.

Rose, J. 1994. Major river systems of central and southern Britain during the Early and Middle Pleistocene. Terra Nova, 6, 435-443.

Rose, J. 2009. Early and middle Pleistocene landscapes of eastern England. Proceedings of the Geologists Association 120, 3-33.

Rose, J., Carney, J.N., Silva, B.N., Booth, S.J. 2010. A striated, far-travelled clast of rhyolitic tuff from Thames river deposits at Ardleigh, Essex, England: evidence for early Middle Pleistocene glaciation in the Thames catchment Netherlands Journal of Geosciences 89, 137146.

Rose, J., Moorlock, B.S.P., Hamblin, R.J.O. 2001. Pre-Anglian fluvial and coastal deposits in Eastern England: lithostratigraphy and palaeoenvironments. Quaternary International 79, 522. 
Rose, J., Schlüchter, C. 1989. Quaternary type sections : imagination or reality? A.A. Balkema, Rotterdam

Rose, J., Smith, M.J. 2008. Glacial geomorphological maps of the Glasgow region, western central Scotland Journal of Maps, 2008, 399-416.

Rowe P.J., Atkinson, T.C. Turner, T. 1999. U-series dating of Hoxnian interglacial deposits at Marks Tey, Essex, England. Journal of Quaternary Science, 14, 693-702

Rowe, P.J., Richards, D.A., Atkinson, T.C., Bottrell, S.H., Cliff, R.A., 1997. Geochemistry and radiometric dating of a Middle Pleistocene peat. Geochemica et Cosmochimica Acta 61, 4201-4211.

Ruegg, G.H.J., Zandstra, J.G. 1977. Pliozäne und Pleistozäne gestaugte Ablagerungen bei Emmerschans (Drenthe, Niederlande). Mededelingen Rijks Geologische Dienst, N.S. 28, 6683

Rühberg, N., Schulz, W., v. Bülow, W., Müller, U., Krienke, H.-D., Bremer, F. Dann, T. 1995. Mecklenburg-Vorpommern. In: Benda, L. (Ed.), Das Quartär Deutschlands, 95-115; Berlin.

Saks, T., Kalvans, A., Zelcs, V. 2012. OSL dating of Middle Weichselian age shallow basin sediments in Western Latvia, Eastern Baltic. Quaternary Science Reviews, 34, please add page numbers.

Salvador, A. (Ed.) 1994. International Stratigraphic Guide - guide to stratigraphic classification, terminology and procedure, $2^{\text {nd }}$ Edition. International Union of Geological Sciences and Geological Society of America, $214 \mathrm{p}$.

Scheib, A.J., Lee, J.R., Breward, N., Riding, J.B. 2011. Reconstructing flowpaths of the Middle Pleistocene British Ice Sheet in central-eastern England : the application of regional soil geochemical data. Proceedings of the Geologists' Association 122, 432-444.

Schuddebeurs, A. P. and Zandstra, J. G. 1983. Indicator pebble counts in the Netherlands. In: Ehlers, J. (ed.) The Glacial Deposits in North-West Europe, 357-361, Rotterdam.

Scourse, J.D., Haapaniemi, A.I., Colmenero-Hidalgo, E., Peck, V.L., Hall, I.R., Austin, W.E.N., Knutz, P.C., Zahn, R. 2009. Growth, dynamics and deglaciation of the last British-Irish ice sheet: the deep-sea ice-rafted detritus record. Quaternary Science Reviews 28, 3066-3084.

Sefström, N.G. 1838. Untersuchungen über die auf den Felsen Skandinaviens in bestimmter Richtung vorhandenen Furchen und deren wahrscheinliche Entstehung. Annalen der Physik und Chemie, 43, 533-567.

Sejrup, H.P., Aarseth, I., Ellingsen, K.L., Reither, E., Jansen, E., Løvlie, R., Bent, A., BrighamGrette, J., Larsen, E., Stoker, M. 1987. Quaternary stratigraphy of the Fladen area, central North Sea: a multidisciplinary study. Journal of Quaternary Science 2, 35-58.

Sejrup, H.P., Aarseth, I., Haflidason, H. 1991. The Quaternary succession in the northern North Sea. Marine Geology 101, 103-111.

Sejrup, H.P., Aarseth, I., Haflidason, H., Løvlie, R., Bratten, A., Tjøstheim, H., Forsberg, C.F., Ellingsen, K.L. 1995. Quaternary of the Norwegian Channel: glaciation history and palaeoceanography. Norsk Geologisk Tidsskrift 75, 65-87.

Sejrup, H.P., Hjelstuen, B.O., Torbjorn Dahlgren, K.I., Haflidason, H., Kuijpers, A., Nygard, A., Praeg, D., Stoker, M.S., Vorren, T.O. 2005. Pleistocene glacial history of the NW European continental margin. Marine and Petroleum Geology 22, 1111-1129. 
Sejrup, H.P., King, E.L., Aarseth, I., Haflidason, H., Elverhøi, A. 1996. Quaternary erosion and depositional processes: western Norwegian fjords, Norwegian Channel and North Sea Fan. Geological Society, London, Special Publications 117, 187-202.

Sejrup, H.P., Larsen, E., Haflidason, H., Berstad, I.M., Hjelstuen, B.O., Jonsdottir, H.E., King, E.L., Landvik, J., Longva, O., Nygård, A., Ottesen, D., Raunholm, S., Rise, L., Stalsberg, K. 2003. Configuration, history and impact of the Norwegian Channel Ice Stream. Boreas 32, 18-36.

Sejrup, H.P., Larsen, E., Landvik, J., King, E.L., Haflidason, H., Nesje, A. 2000. Quaternary glaciations in southern Fennoscandia: evidence from southwestern Norway and the northern North Sea region. Quaternary Science Reviews 19, 667-685.

Sejrup, H.P., Nygård, A., Hall, A.M., Haflidason, H. 2009. Middle and Late Weichselian (Devensian) glaciation history of south-western Norway, North Sea and eastern UK. Quaternary Science Reviews 28, 370-380.

Seppä, H., Bennett, K.D., 2003. Quaternary pollen analysis: recent progress in palaeoecology and palaeoclimatology. Progress in Physical Geography 27, 548-579.

Shackleton, N.J., Hall, M.A., Pate, D. 1995. Pliocene stable isotope stratigraphy of OPD Site 864. In: Pisias, N.G., Mayer, L.A., Janecek, T.R., Palmer-Julson, A., Van Andel, T.H. (Eds.), Proceedings of the Ocean Drilling Program, Scientific Results, 138, 337-355.

Shotton, F.W. 1976. Amplification of the Wolstonian Stage of the British Pleistocene. Geological Magazine, 113, 241-250.

Shotton, F.W. 1983. The Wolstonian Stage of the British Pleistocene in and around its type area of the English Midlands. Quaternary Science Reviews, 2, 261-280.

Sissons, J.B. 1967. The Evolution of Scotland's Scenery, Oliver and Boyd.

Skupin, K., Speetzen, E., Zandstra, J.G. 1993. Die Eiszeit in Nordwestdeutschland. Geologisches Landesamt Nordrhein-Westfalen, Krefeld (1993) pp. 143

Smed, P. 1989. Sten i det danske landskab. 181p.

Smith, M.J., Rose, J., Booth, S. 2006. Geomorphological mapping of glacial landforms from remotely sensed data: an evaluation of the principal data sources and an assessment of their quality, Geomorphology, 76, 148-165.

Stewart, M.A., Lonergan, L., 2011. Seven glacial cycles in the middle-late Pleistocene of northwest Europe: Geomorphic evidence from buried tunnel valleys. Geology 39, 283-286.

Stoker, M.S. 1990. Glacially-influenced sedimentation on the Hebridean Slope, northwestern United Kingdom continental margin. In: Dowdeswell, J.A., Scourse, J.D. (Eds.), Glacimarine Environments: Processes and Sediments. Geological Society, London. Special Publications, 53, 349-362.

Stoker, M.S. 1995. The influence of glacigenic sedimentation on slope apron development on the continental margin off Northwest Britain. In: Scrutton, R.A., Stoker, M.S., Shimmield, G.B., Tudhope, A.W. (Eds.), The Tectonics, Sedimentation and Palaeoceanography of the North Atlantic Region. Geological Society, London. Special Publications, 90, 159-177.

Stoker, M.S. 1997. Mid- to late Cenozoic sedimentation on the continental margin off NW Britain. Journal of the Geological Society 154, 509-515.

Stoker, M.S., Bent, A. 1985. Middle Pleistocene glacial and glaciomarine sedimentation in the west central North Sea. Boreas 14, 325-332. 
Stoker, M.S., Bradwell, T., Howe, J.A., Wilkinson, I.P., McIntyre, K. 2009. Lateglacial ice-cap dynamics in NW Scotland: evidence from the fjords of the Summer Isles region. Quaternary Science Reviews 28, 3161-3184.

Stoker, M.S., Long, D., Fyfe, A.J. 1985. The Quaternary succession in the central North Sea. Newsletters on Stratigraphy 14, 119-128.

Stokes, C.R., Clark, C.D. 2001. Palaeo-ice streams. Quaternary Science Reviews 20, 14371457.

Straw, A. 1979. The geomorphological significance of the Wolstonian glaciation of eastern England. Transactions of the Institute of British Geographers, New Series 4, 540-549.

Sumbler, M.G. 1995. The terraces of the rivers Thame and Thames and their bearing on the chronology of glaciation in central and eastern England. Proceedings of the Geologists' Association 106, 93-106.

Sumbler, M.G. 2001. The Moreton Drift: a further clue to glacial chronology in central England. Proceedings of the Geologists' Association 112, 13-27.

Svendsen, J.I., Alexanderson, H., Astakhov, V.I., Demidov, I., Dowdeswell, J.A., Funder, S., Gataullin, V., Henriksen, M., Hjort, C., Houmark-Nielsen, M., Hubberten, H.W., Ingólfsson, Ó., Jakobsson, M., Kjær, K., Larsen, E., Lokrantz, H., Lunkka, J.P., Lyså, A., Mangerud, J., Matiouchkov, A., Murray, A., Möller, P., Niessen, F., Nikolskaya, O., Polyak, L., Saarnisto, M., Siegert, C., Siegert, M.J., Spielhagen, R.F., Stein, R. 2004. Late Quaternary ice sheet history of northern Eurasia. Quaternary Science Reviews 23, 1229-1271.

Synge, F.M. 1978. Pleistocene events. In: Davies, G.L., Stephens, N. (Eds.), Ireland. Methuen and Co Ltd., London, pp. 115-180.

TGL 25 232, Blatt 1-6. Fachbereichsstandard Geologie: Analyse des Geschiebebestandes quartärer Grundmoränen. DDR, November 1971.

Thierens, M, Pirlet, H., Colin, C., Latruwe, K., Vanhaecke, F., Lee, J.R., Stuut, J.-B., Titschack, J., Huvenne, V.A.I., Dorschel, B., Wheeler, A.J., J.-P. Henriet, J.-P. 2012. Icerafting from the British-Irish ice sheet since the earliest Pleistocene (2.6 million years ago): implications for long-term mid-latitudinal ice-sheet growth in the North Atlantic region. Quaternary Science Reviews, 34, please add page numbers.

Thompson, W.G., Goldstein, S.L. 2006. A radiometric calibration of the SPECMAP timescale. Quaternary Science Reviews 25, 3207-3215

Thomsen, K.J., Murray, A.S., Jain, M., Bøtter-Jensen, L. 2008. Laboratory fading rates of various luminescence signals from feldspar-rich sediment extracts. Radiation Measurements 43, 1474-1486.

Torrell, O. 1875. Schliff-Flächen und Schrammen auf der Oberfläche des Muschelkalks von Rüdersdorf. Zeitschrift der deutschen geologischen Gesellschaft 27, 961-962.

Toucanne, S., Zaragosi, S., Bourillet, J.F., Gibbard, P.L., Eynaud, F., Giraudeau, J., Turon, J.L., Cremer, M., Cortijo, E., Martinez, P., Rossignol, L. 2009. A 1.2 Ma record of glaciation and fluvial discharge from the West European Atlantic margin. Quaternary Science Reviews 28, 2974-2981.

Urban, B., Sierralta, M., Frechen, M. 2011. New evidence for vegetation development and timing of Upper Middle Pleistocene interglacials in Northern Germany and tentative correlations. Quaternary International 241, 125-142.

Ussing, N. V., Madsen, V. 1897. Beskrivelse til det geologiske kortblad Hindsholm. Danmarks Geologiske Undersøgelse, raekke 1, 2, 87 p. 
Vandenberghe, J. 2000. A global perspective of the European chronostratigraphy for the past 650 ka. Quaternary Science Reviews 19, 1701-1707.

Van der Vlerk, I. M. and Florschütz, F. 1950. Nederland in het ljstijdvak. De Haan, Utrecht.

Van der Wateren, F.M. 2005. Ice-marginal terrestrial landsystems: Southern Scandinavian Ice Sheet Margin, In: Evans, D.J.A. (Ed.), Glacial Landsystems. Hodder Arnold, London, pp. 166-203.

Velichko, A.A., Faustova, M.A., 1986. Glaciations in the East European region of the USSR. Quaternary Science Reviews 5, 447-461.

Velichko, A.A., Faustova, M.A., Gribchenko, Y.N., Pisareva, V.V., Sudakova, N.G., 2004. Glaciations of the East European Plain-distribution and chronology, In: Ehlers, J., Gibbard, P.L. (Eds.), Developments in Quaternary Science. Elsevier, pp. 337-354.

Viiding, H., Gaigalas, A. Gudelis, V., Raukas, A., Tarvydas, R. 1971. Crystalline Indicator Boulders in the East Baltic Area. - Vilnius (in Russian).

Vinx, R., Grube, A., Grube F. 1997. Vergleichende Lithologie, Geschiebeführung und Geochemie eines Prä-Elster-I Tills von Lieth bei Elmshorn. Leipziger Geowissenschaften 5, 83-103.

Vorren, T.O., Laberg, J.S. 1997. Trough mouth fans - palaeoclimate and ice-sheet monitors. Quaternary Science Reviews 16, 865-881.

Wagenbreth, O., Steiner, W. 1990. Geologische Streifzüge.

Wagner, T., Henrich, R. 1994. Organo- and lithofacies of glacial-interglacial deposits in the Norwegian-Greenland Sea: Responses to paleoceanographic and paleoclimatic changes. Marine Geology 120, 335-364.

Wallinga, J., Murray, A., Wintle, A. 2000. The single-aliquot regenerative-dose (SAR) protocol applied to coarse-grain feldspar. Radiation Measurements 32, 529-533.

Weerts, H.J.T., Westerhoff, W.E., Cleveringa, P., Bierkens, M.F.P., Veldkamp, J.G., Rijsdijk, K.F. 2005. Quaternary geological mapping of the lowlands of The Netherlands, a 21st century perspective. Quaternary International 133-134, 159-178.

West, R.G. 1977. Pleistocene Geology and Biology. Longmans, London.

West, R.G., Donner, J.J., 1956. The glaciations in East Anglia and the East Midlands: a differentiation based on stone-orientation measurements of the tills. Quarterly Journal of the Geological Society of London 112, 69-91.

Westaway, R. 2009. Quaternary vertical crustal motion and drainage evolution in East Anglia and adjoining parts of southern England: chronology of the Ingham River terrace deposits. Boreas 38, 261-284.

Westaway, R. 2011. The Pleistocene terrace staircase of the River Thame, central-southern England, and its significance for regional stratigraphic correlation, drainage development, and vertical crustal motions. Proceedings of the Geologists' Association 122, 92-112

Westaway, R., Maddy, D., Bridgland, D. 2002. Flow in the lower continental crust as a mechanism for the Quaternary uplift of south-east England: constraints from the Thames terrace record. Quaternary Science Reviews 21, 559-603.

Westerhoff, W.E., Wong, T.E., Geluk, M.C. 2003. De opbouw van de ondergrond. In: E.F.J. De Mulder, M.C. Geluk, I. Ritsema, W.E. Westerhoff, T.E. Wong (Eds.), De Ondergrond Van Nederland, Nederlands Instituut Voor Toegepaste Geowetenschappen TNO, 247-352 Geologie van Nederland 
White, T.S., Bridgland, D.R., Westaway, R., Howard, A.J., White, M.J. 2010. Evidence from the Trent terrace archive, Lincolnshire, UK, for lowland glaciation of Britain during the Middle and Late Pleistocene. Proceedings of the Geologists' Association 121, 141-153

Wiederhold, H. (ed.) 2009: Buried Glacial Valleys. Zeitschrift der Deutschen Gesellschaft für Geowissenschaften, 16, 3.

Whiteman, C.A. 1992. The palaeogeography and correlation of pre-Anglian-Glaciation terraces of the River Thames in Essex and the London Basin. Proceedings of the Geologists' Association 103, 37-56.

Whiteman, C.A., Rose, J. 1992. Thames river sediments of the British Early and Middle Pleistocene. Quaternary Science Reviews 11, 363-375.

Wingfield, R.T.R. 1990. Glacial incisions indication Middle and Upper Pleistocene ice limits off Britain. Terra Nova 1, 538-548.

Wintle, A.G. 2008a. Luminescence dating. Where it has been and where it is going. Boreas 37, 471-482.

Wilson, L.J., Austin, W.E.N. 2002. The last British Ice Sheet: growth, maximum extent and deglaciation. Polar Research 21, 242-250.

Wintle, A.G. 2008b. Fifty years of luminescence dating. Archaeometry 50, 276-312.

Wintle, A.G., Huntley, D.J. 1979. Thermoluminescence dating of a deep-sea ocean core. Nature $279,710-712$.

Wintle, A.G., Murray, A.S. 2006. A review of quartz optically stimulated luminescence characteristics and their relevance in single-aliquot regeneration dating protocols. Radiation Measurements 41, 369-391.

Woldstedt, P. 1925. Die großen Endmoränenzüge Norddeutschlands. Zeitschrift der Deutschen Geologischen Gesellschaft 77, 172-184.

Woldstedt, P. 1927. Die Gliederung des Jüngeren Diluviums in Norddeutschland und seine Parallelisierung mit anderen Glazialgebieten. Zeitschrift der deutschen Geologischen Gesellschaft, Monatsberichte 1927, 3/4, 51-52.

Woldstedt, P. 1935. Geologisch-morphologische Übersichtskarte des norddeutschen Vereisungsgebietes. Preußische Geologische Landesanstalt, Berlin.

Woldstedt, P. 1954. Saaleeiszeit, Warthestadium und Weichseleiszeit in Norddeutschland. Eiszeitalter und Gegenwart 4/5, 34-48.

Wysota, W., Lankauf, K.R., Szmanda, J., Chruscinska, A., Oczkowski, H.L., Przegietka, K.R. 2002. Chronology of the Vistulian (Weichselian) glacial events in the Lower Vistula Region, Middle-North Poland. Geochronometria 21, 137-142.

Wysota, W., Molewski, P., Sokolowski, R.J. 2009. Record of the Vistula ice lobe advances in the Late Weichselian glacial sequence in north-central Poland. Quaternary International 207, 266-41.

Zagwijn, W.H. 1986. The Pleistocene of the Netherlands with special reference to glaciation and terrace formation. Quaternary Science Reviews 5, 341-345.

Zagwijn, W.H., 1989. An outline of the Quaternary stratigraphy of the Netherlands. Geologie en Mijnbouw 64, 17-24. 
Zagwijn, W.H., 1996. The Cromerian Complex stage of the Netherlands and correlation with other areas in Europe, In: Turner, C. (Ed.), The Early Middle Pleistocene in Europe. Balkema, Rotterdam, pp. 145-172.

Zandstra, J.G. 1971. Geologisch onderzoek in de stuwwal van de Oostelijke Veluwe bij Hattem en Wapenveld. Mededelingen Rijks Geologische Dienst N.S. 22, 215-260.

Zandstra, J.G. 1983. Fine gravel, heavy mineral and grain-size analyses of Pleistocene, mainly glaciogenic deposits in the Netherlands. In: J. Ehlers (Ed.), Glacial Deposits in NorthWest Europe, Balkema, Rotterdam (1983), pp. 361-377 


\section{Captions of Figures and Table}

Figure 1. Ice flow trends and glacier margins of the Scandinavian Ice Sheet reconstructed from glacial lineaments and ice marginal landforms. Taken from Boulton et al., 2001, Figure 11, copyright Elsevier.

Figure 2. Glacial terrain of the Solway lowland region of northwest England/ southwest Scotland shown using NEXTMap ${ }^{\text {тM }}$ imagery. The image shows in particular the drumlins and other glacial lineaments formed by different ice streams (indicated by different colours), and forming at different times. Overprinting of lineaments by one ice stream, upon existing lineaments formed by an earlier ice stream can be seen in the upper central part of the NEXTMap ${ }^{\mathrm{TM}}$ image. The block in the lower right hand corner of the lower figure gives the sequence of events as derived from the crosscutting relationships and the interaction of the different ice flow systems. Taken from Livingstone et al., 2010, Figure 3, copyright Elsevier.

Figure 3. Sea-bed glacial landscape of northern and northeast Scotland shown by the Olex bathymetric database compiled, processed and managed by the Norwegian company Olex AS (www.olex.no). The sea-bed image is based upon echo sounder data acquired mainly by commercial fishing vessels, but also including data from research vessels. The terrestrial terrain is revealed by NEXTMap ${ }^{\text {TM }}$. The upper figure shows the pattern of moraine ridges and lineaments on the sea-bed, the lower figure shows the interpretation of these features (blue, red and green lines are moraine ridges and dashed lines are erosional channels. Taken from Bradwell et al., 2008, Figure 4 and 5, copyright Elsevier.

Figure 4. Models for late Middle Pleistocene glaciation in the British Isles. A) The 'early traditional' model of Mitchell et al. (1973) showing the limits of the Anglian and Wolstonian glaciations and the type sites for the deposits of these glaciations. Taken from West (1977), Figure 12.3. B) The 'traditional' model of Bowen et al. (1986) showing the dominant extent of the Anglian Glaciation and inferred limits of other late Middle Pleistocene glaciations. Taken from Bowen et al. (1986), Figure 5. C) A modification of the traditional model, published in Gibbard and Clark, 2011, Figure 7.2. D) The multi-stage late Middle Pleistocene glaciation model. Described and published electronically in Clark et al. (2004) and elaborated in Hamblin et al. (2005) and Rose (2009).

Figure 5. Age estimates on the outer limit of the SIS and BIIS during the Last Glaciation (MIS 2). The ages are taken from the papers included in the QSR volume on Quaternary Glaciations of northern Europe including the British Isles. Age estimates are derived from a number of sources as described in Marks (2012), Rinterknecht et al. (2012), Clark et al. (2012) (scenario 2) and Ó Cofaigh et al. (2012b). A correlation of the various margins along with their local names is given in Table 1. Evidence for the ice marginal positions shown at the southern margin of the SIS relate to morphostratigraphic features as explained in Kalm (2101, Bitinas (2012) Marks (2012), Lüthgens and Böse (2012), Rinterknecht et al. (2012) and Ó Cofaigh et al. (2012b), but in the case of those identified in Clark et al. (2012), while including margins that are represented morphostratigraphically, also includes lines that are derived from a number of dates on relation to the stratigraphic sequence and the geographical position. The dates given clearly show the diachronous nature of the outer limit (the LGM by definition). The merging of marginal lines and the disappearance of others shows that, respectively, some marginal positions were fixed for relatively long periods of time, relative to other positions and that other sites reveal evidence for local readvance. All of this demonstrates that the behaviour of the glacier is function of the behaviour of the various ice streams that drained the SIS and BIIS, a factor that is demonstrated in many of the papers in the volume. 
Table 1 Correlation of ice marginal positions of the SIS and BIIS, using data taken from Quaternary Glaciations of Northern Europe including the British Isles. Terms such as 'stage', 'phase', 'moraine', oscillation, expansion, or zone are not used in the table although these terms are used informally and variously in all the localities. Where the terms are given in italics, no age estimate has been given and correlation is made by morphostratigraphic correlation, and morphostratigraphic correlation may be important in determining the relationships and continuity of features, even when age estimates are available. The absence of younger names in Ireland and Britain is due to the absence of any regionally extensive marginal features associated with ice wastage over this period of time and any widely used/ accepted names. The marginal positions shown in Clark et al. (2012), some of which are shown in Figure 4 of this paper, are determined by the use of dates related to the glacial sequence. Data is obtained from Table 1 in Bitinas (2012), Table 1 of Marks (2012), Litt (2007), Ó Cofaigh et al. (2012b), Clark et al. (2012), Evans et al. (2005) and Kalm (2012) from which the numbers in the left hand column are obtained. It should be stressed however, that these numbers only apply to the southeastern margin of the SIS in view of the diachronous nature of the ice streams that formed the different outer limits of the SIS and BIIS. 
Figure 1

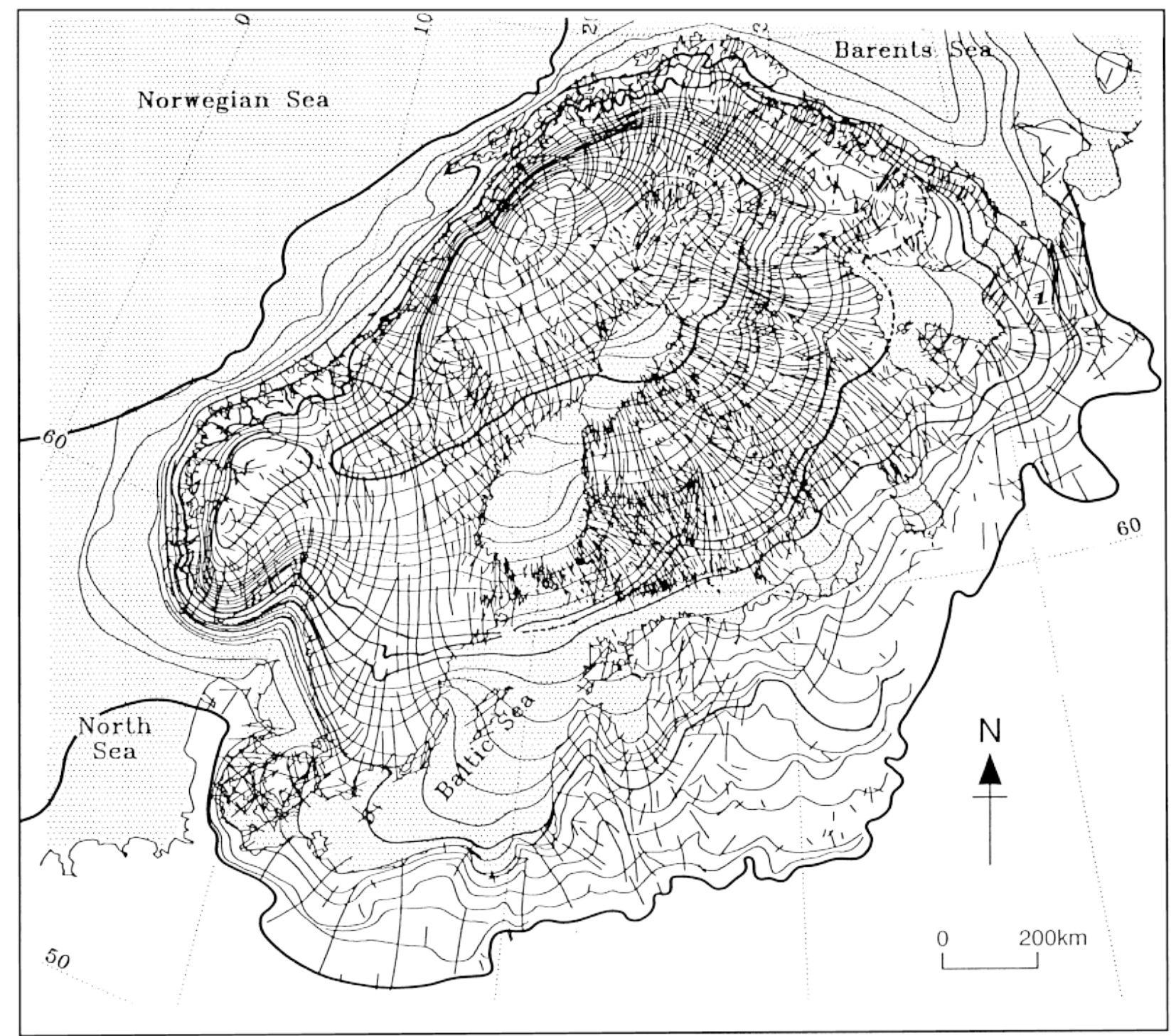


Figure 2

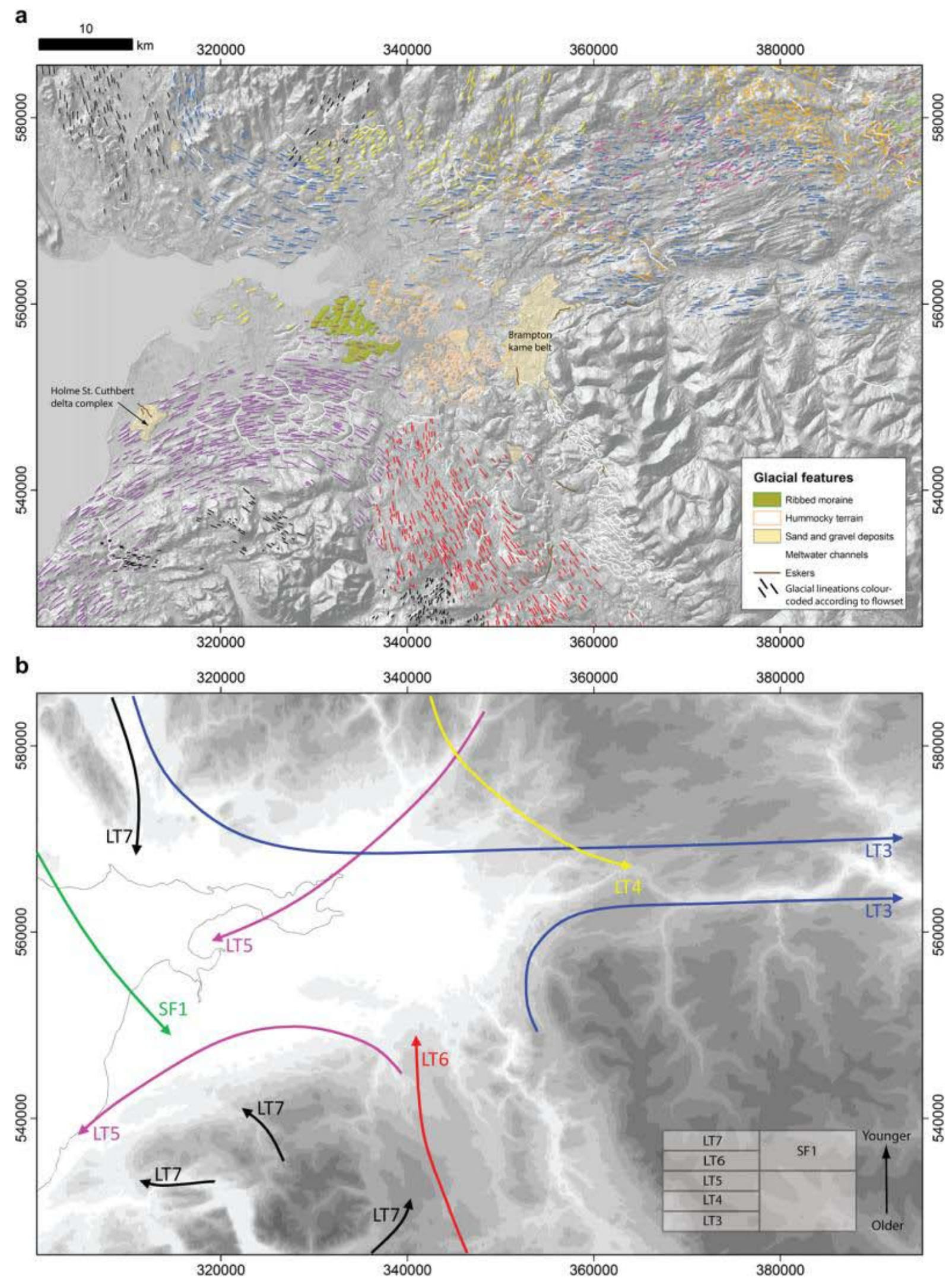


Figure 3
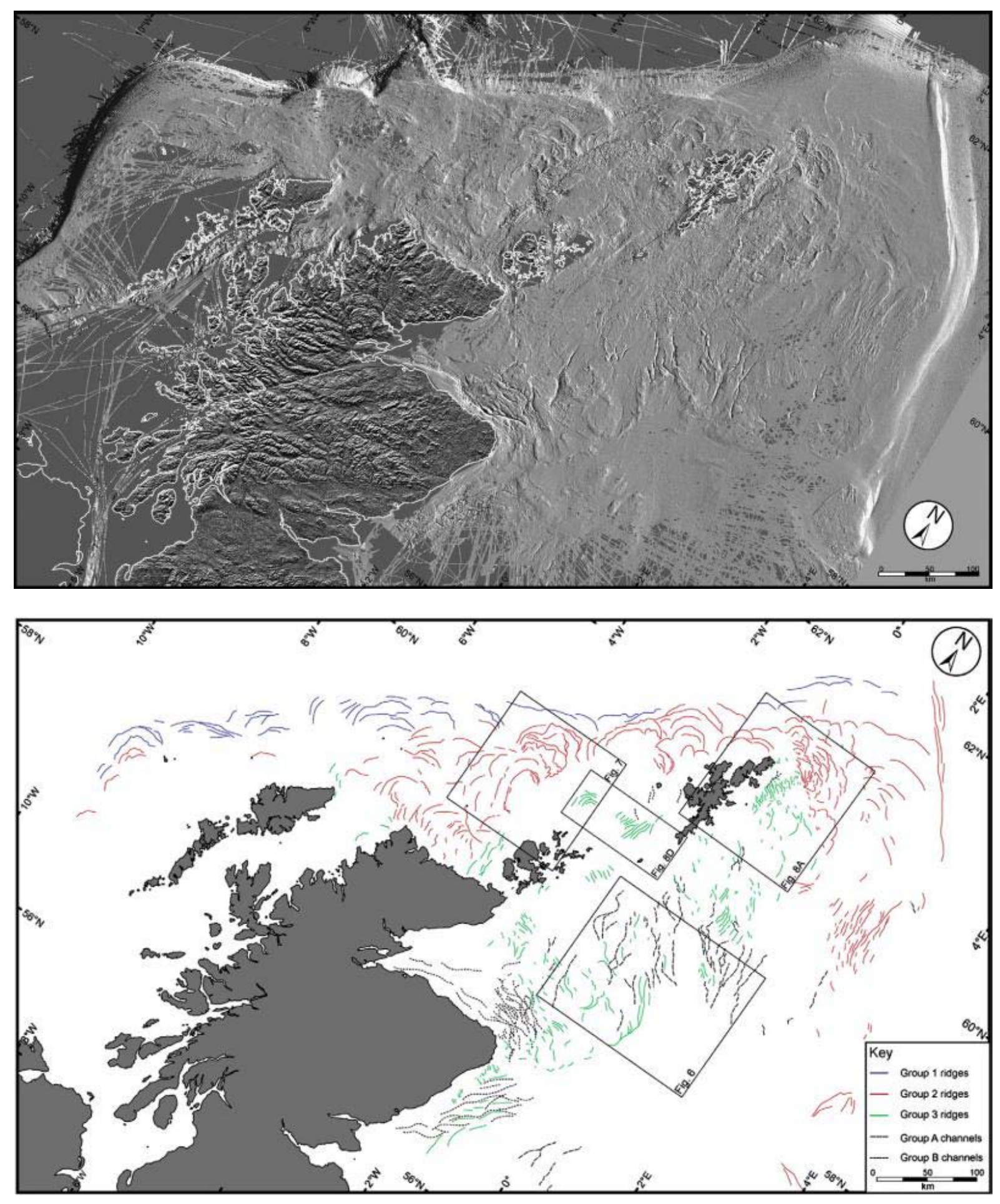

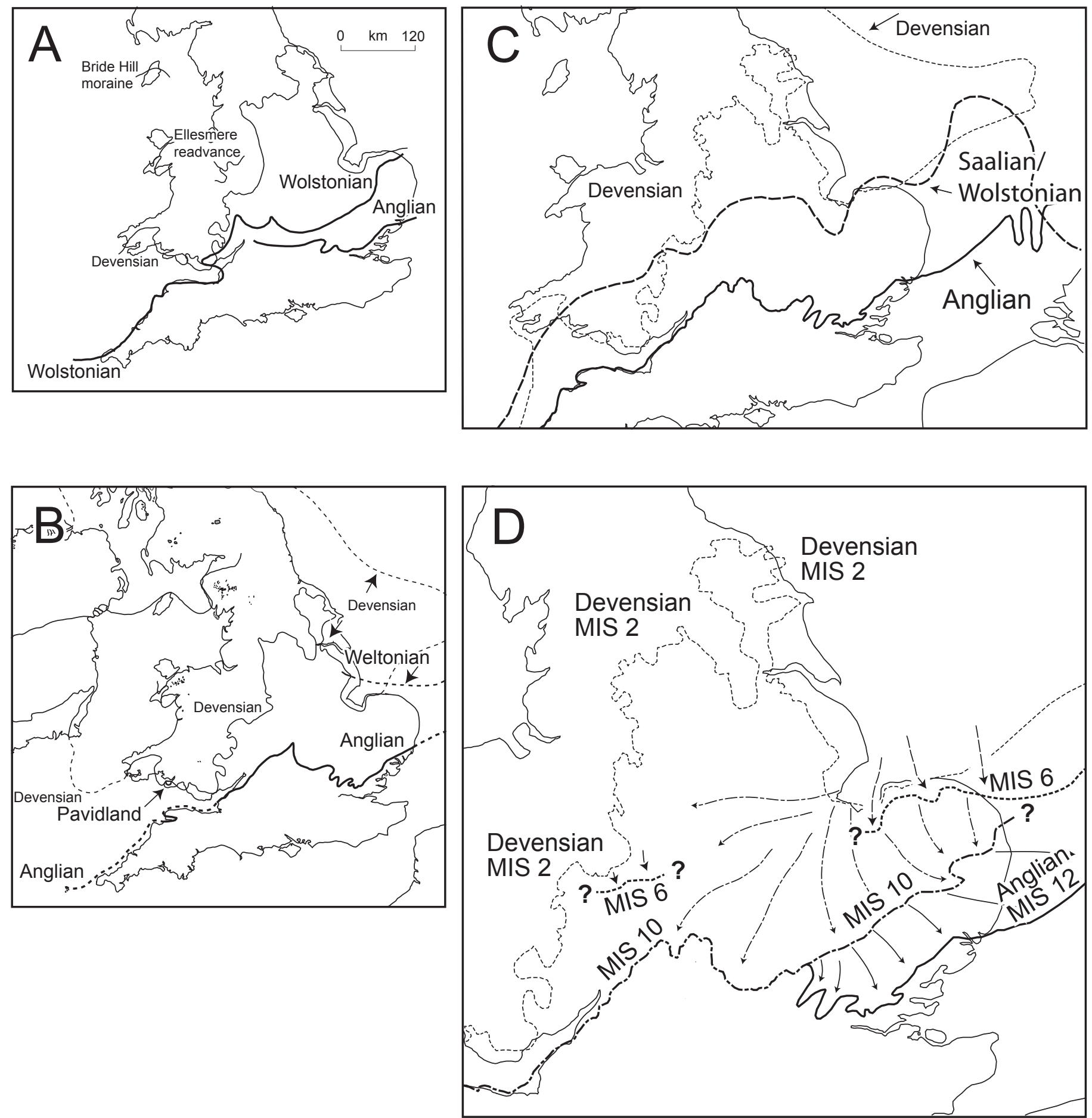


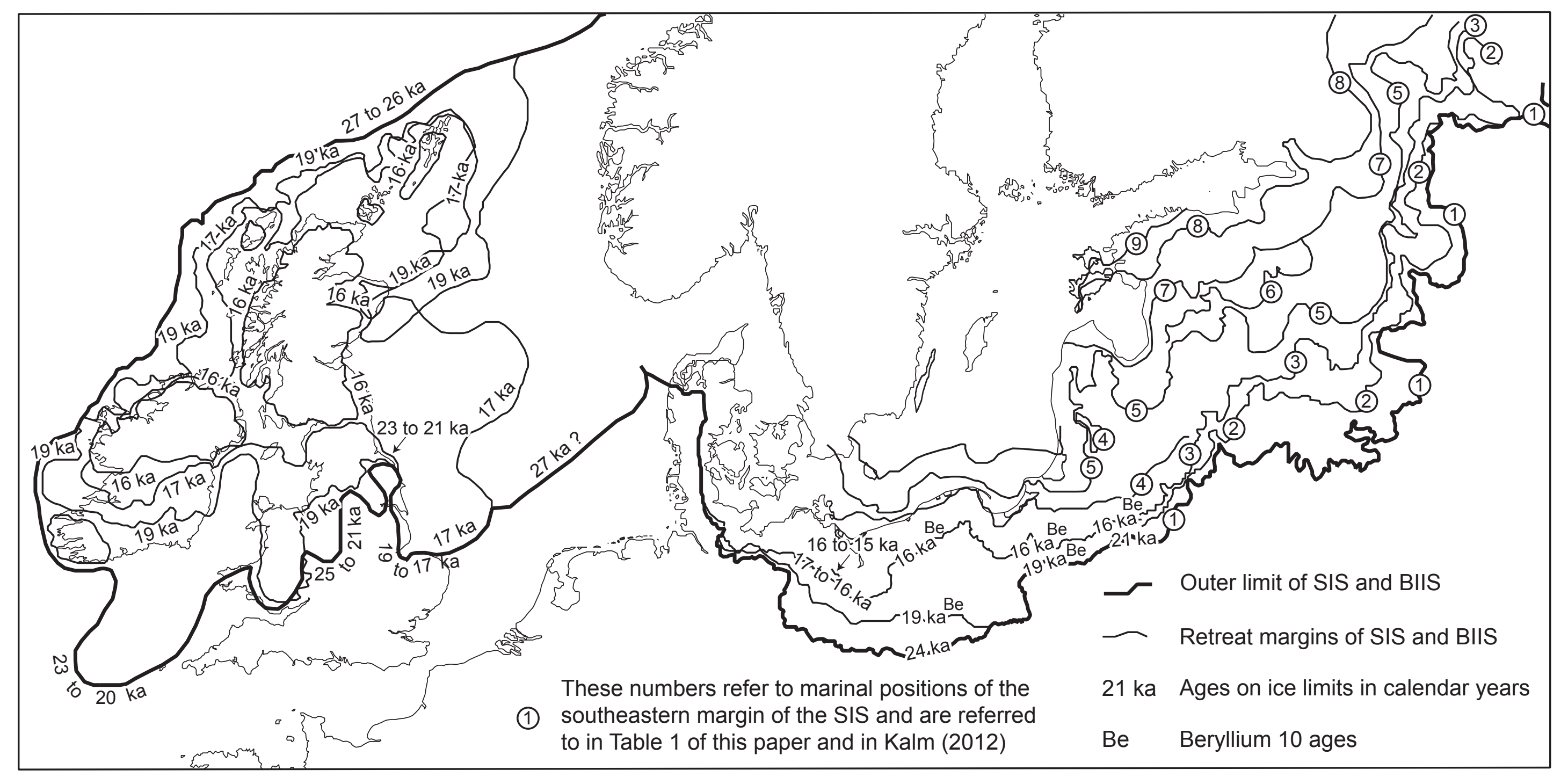


Table 1

\begin{tabular}{|c|c|c|c|c|c|c|c|}
\hline $\begin{array}{l}\text { Age or } \\
\text { number given } \\
\text { on Figure } 4 \\
\text { for Lithuania, } \\
\text { Latvia \& } \\
\text { Estonia }\end{array}$ & Ireland & Britain & Germany & Poland & Lithuania & Latvia & Estonia \\
\hline 9 & & & & & & & Palivere \\
\hline 8 & & & & & & & Pandivere \\
\hline 7 & & & & & Pajüris & Valdemarpils & \\
\hline 6 & & & & & & & Otepää \\
\hline 5 & & & & $\begin{array}{l}\text { South Middle } \\
\text { Bank }\end{array}$ & $\begin{array}{l}\text { North } \\
\text { Lithuanian }\end{array}$ & Linkuva & Haanja \\
\hline 4 & & & & Slupsk Bank & $\begin{array}{l}\text { Middle } \\
\text { Lithuanian }\end{array}$ & Gulbene & \\
\hline $\begin{array}{l}16 \text { to } 15 \mathrm{ka} \\
3\end{array}$ & & Bride/ Scottish & $\begin{array}{l}\text { Mecklenburg/ } \\
\text { Gerswalder }\end{array}$ & Gardno & $\begin{array}{l}\text { South } \\
\text { Lithuanian }\end{array}$ & Dagda & \\
\hline $\begin{array}{l}17 \text { to } 16 \mathrm{ka} \\
2\end{array}$ & Drumlin & Dimlington & Pomeranian & Pomeranian & Baltija & $\begin{array}{l}\text { Major glacier } \\
\text { expansion }\end{array}$ & \\
\hline $\begin{array}{l}21 \text { t0 } 19 \text { ka } \\
1\end{array}$ & South Ireland & $\begin{array}{l}\text { Clwyd \& east } \\
\text { Yorkshire }\end{array}$ & Frankfurt & Poznan & Grüda & & \\
\hline 25 to $20 \mathrm{ka}$ & $\begin{array}{l}\text { Celtic Sea } \\
\text { margin }\end{array}$ & Cheshire & Brandenburg & Leszno & & & \\
\hline 29 to $26 \mathrm{ka}$ & Shelf margin & $\begin{array}{l}\text { Shelf margin \& } \\
\text { S North Sea }\end{array}$ & & & & & \\
\hline
\end{tabular}

